\title{
Turbiditic levee deposition in response to climate changes: The Var Sedimentary Ridge (Ligurian Sea)
}

Stéphan J. Jorry $^{\mathrm{a}, *}$, Isabelle Jégou ${ }^{\mathrm{a}}$, Laurent Emmanuel ${ }^{\mathrm{b}}$, Ricardo Silva Jacinto ${ }^{\mathrm{a}}$ and Bruno Savoye ${ }^{\mathrm{a}}$

\author{
a IFREMER, Géosciences Marines, Laboratoire Environnements Sédimentaires, BP 70, 29280 \\ Plouzané, France \\ ${ }^{\mathrm{b}}$ Université Pierre \& Marie CURIE, Laboratoire Biominéralisations et Environnements Sédimentaires, \\ ISTeP-UMR CNRS 7193, CP 1164 Place Jussieu, 75252 Paris Cedex 05, France
}

\author{
*: Corresponding author : Stéphan J. Jorry, Tel.: + 332982242 32; fax: + 3329822 45 70, email \\ address: stephan.jorry@ifremer.fr
}

\begin{abstract}
:
The Var turbiditic system located in the Ligurian Sea (SE France) is an intermediate mud/sand-rich system. The particularity of the Var deep-sea fan is its single channel with abrupt bends and its asymmetric and hyper-developed levee on the right hand side: the Var Sedimentary Ridge. Long-term sediment accumulation on the Var Sedimentary Ridge makes this an ideal target for studying the link between onshore climate change and deep-sea turbidite stratigraphy. This paper focuses on the establishment of the first detailed stratigraphy of the levee, which is used to analyze the timing of overbank deposition throughout the last deglaciation. Main results indicate that high variability in turbidite frequencies and deposition rates along the Var Sedimentary Ridge are determined by two main parameters: 1 ) the progressive decrease of the levee height controlling the ability of turbidity currents to spill out from the channel onto the levee, and 2) climatic variations affecting the drainage basin, in particular changes in glacial condition since late Last Glacial Maximum to early Holocene. Compared to other deep-water areas, this study confirms the ability of turbiditic systems to record past climatic events on millennial timescales, and underlines the influence of European deglaciation on the observed decrease in turbidite activity in the Var canyon. The presence of a very narrow continental shelf and a single, large channel-levee system makes the Var Sedimentary Ridge a unique example of climate-controlled turbiditic accumulations.
\end{abstract}

Keywords: last deglaciation; overbank deposits; turbidity currents; Var Sedimentary Ridge; Ligurian Sea 


\section{Introduction}

The turbidity currents responsible for levee deposition have been pictured as having episodic or continuous overspill that transfers sediment from the channel to the levees ([Chough and Hesse, 1977], [Clark and Pickering, 1996], [Clark et al., 1992], [Hiscott et al., 1997], [Normark et al., 1983] and Piper and Normark, 1983 D.J.W. Piper and W.R. Normark, Turbidite depositional patterns and flow characteristics, Navy submarine fan, California borderland, Sedimentology 30 (5) (1983), pp. 681-694. Full Text via CrossRef | View Record in Scopus | Cited By in Scopus (120)[Piper and Normark, 1983]). As the growth of a levee starts almost at the initiation of a turbidite system, it may consequently produce an almost continuous record of the dynamic of gravity flows.

Linkages between the dynamic of turbiditic systems and allocyclic factors such as climate and sea level changes have been long demonstrated in basins adjacent to continental margins. This is particularly true for turbidites deposited along both siliciclastic (e.g. [Bouma, 1982] and [Gibbs, 1981]) and carbonate ([Dubar and Anthony, 1995], [Glaser and Droxler, 1991], [Jorry et al., 2010] and [Schlager et al., 1994]) margins over the last few glacial cycles. Since the past few years, only a few studies have tested the large potential of turbiditic systems to study the impact of millennial timescale climatic/eustatic signals on geometry, partitioning, and stacking pattern of such deep-water sedimentary accumulations. 
At high latitudes, Skene and Piper (2003) described thick accumulations of turbidites that recorded rapid changes in discharge of sediment-laden subglacial water associated with the rapid retreat of ice from the mouth of Laurentian Channel (from 21 to 17 cal ka BP). Highresolution sedimentological and micropaleontological studies of several deep-sea cores retrieved from the levees of the Celtic and Armorican turbidite systems (Bay of Biscay-North Atlantic Ocean) allowed the detection of major oscillations of the British-Irish Ice Sheet and "Fleuve Manche" palaeoriver discharges during the last 30,000 years, which were mainly triggered by climate changes (Toucanne et al., 2008). At low latitudes, the study of sediment cores collected in the central part of Pandora Trough (Gulf of Papua, SW Pacific) has revealed a detailed sedimentary pattern of eustatically controlled turbiditic deposits on millennial timescale during the last glacial/interglacial cycle (Carson et al., 2008; Jorry et al., 2008). Recently, Pierau et al. (2009) demonstrated that the highest frequency in turbidite activity in the Dakar Canyon was confined to major climatic terminations during the late sea-level rise.

The study of the Var deep-sea fan started during the sixties (Bourcart, 1960; Gennesseaux, 1962), and was followed by several studies which focused on the emerged part of the Var delta (Clauzon, 1978; Irr, 1984; Clauzon et al., 1990). The interest in the submarine part of the system was enhanced by the occurrence of a large catastrophic numerous Seabeam surveys were acquired from 1980 to 1983, providing new data which increased the understanding of the Var deep-sea fan morphology (Pautot, 1981; Pautot et al., 1984). During the last twenty years, seismic reflection profiles have been collected across the entire Var turbidite system, including the southern levee, allowing Savoye et al. (1993) to

81 reconstruct the paleogeographic evolution of the Var deep-sea fan during the Plio-

82 Pleistocene. As a result of increased data availability, numerous studies have also focused 
wave field located on the eastern part of the Var Sedimentary Ridge (VSR) (Foucault et al., 1986a; Foucault et al., 1986b; Piper and Savoye, 1993; Savoye et al., 1993; Migeon et al., 2000; Migeon et al., 2001; Migeon et al., 2006).

Despite numerous studies that have contributed to define the Var system as a reference for turbiditic accumulations along channel-levee systems, no study has focused on the late Quaternary turbidite activity of the Var system with respect to global climate changes. The absence of high-resolution stratigraphy on the VSR represents a gap in the understanding of forcing parameters controlling the deposition and recurrence frequency of overflows during the late Quaternary. Here we demonstrate that the VSR is an appropriate target for studying the overbank deposits on millennial timescales. The objectives of this paper are 1) to establish the first published stratigraphy of the VSR since the Last Glacial Maximum (LGM) (ca 26 to 18 cal ka BP), 2) to quantify the variability of the turbiditic activity and sediment accumulation on the VSR from late LGM to early Holocene, 3) to discuss the potential links between overbank deposition and climatic events on millennial timescales, and 4) to compare the stratigraphy and the sedimentary record on Var turbidite system with that of other deep-water areas located at low and high latitudes.

\section{Physical and geological settings}

\section{Rivers and drainage basin}

Narrow valleys bordering the coastal plain of Nice (Baie des Anges) are commonly occupied by short coastal streams (Figure 1) having seasonal but erratic and torrential discharge regimes, typical of the Alpine flank of the Mediterranean. The largest river is the Var, whose headwaters reach altitudes of 2000 to 2500 m (Figure 1). The Var River has a drainage basin of about $2800 \mathrm{~km}^{2}$ (Figure 1 and Figure 2) and a pronounced seasonal water discharge with large flash floods in autumn and spring. The basement lithology in the 
112 drainage basin is dominated by black shales that provide easily erodable fine particles that 113 are transported in suspension (Mulder et al., 1998). Mean annual fluvial discharge is 70 $114 \mathrm{~m}^{3} / \mathrm{sec}$ and can range from $20 \mathrm{~m}^{3} / \mathrm{sec}$ to over $800 \mathrm{~m}^{3} / \mathrm{sec}$ in a few hours (Dubar and 115 Anthony, 1995). The solid load of the Var contains about 10 million $\mathrm{m}^{3} / \mathrm{yr}$ of fine suspended sediment (Thèvenin, 1981) and about 100,000 $\mathrm{m}^{3} / \mathrm{yr}$ of gravel (Sage, 1976). Other shorter,

117 coastal streams as the Paillon and Roya rivers are fed by much smaller catchments (Figure 118 2), which are characterized by steep channel gradients in the upper reaches. For example, $11951 \%$ of the 40-km-long Paillon catchment lies between 500 and $1000 \mathrm{~m}$.

120

The Baie des Anges coastal area is microtidal (range $<0.5 \mathrm{~m}$ at equinox tides) and is exposed to fetch-limited, low-energy wind waves with mean and significant heights of 0.6 and $0.96 \mathrm{~m}$. This low wave-energy regime is punctuated by storm conditions during which wave height may exceed $2 \mathrm{~m}$ a few days in the year.

During the LGM, the Alps were almost completely covered by the late Würmian ice sheet (Florineth and Schluchter, 1998; Hinderer, 2001). According to the reconstruction proposed by Buoncristiani and Campy (2004b), the Var drainage basin was connected to the late Würmian ice sheet with the Tinée glacier, the Vesubie glacier, and part of the Ubaye glacier (Figure 2). Based on the extent of end morains, these glaciers covered about $17 \%$ of the Var drainage basin area (around $476 \mathrm{~km}^{2}$ ). Also, the southern Alps contain many rock glaciers, some of which are still active today (Evin, 1983; Evin and Fabre, 1990). The main rock glaciers of the Var drainage basin are: Barres de la Bonette, Braisses, Gorgias, Trou de I'Aigle, and Pelat. As defined by Ivy-Ochs et al. (2008), the "Alpine Lateglacial" (ca 11.6 to 18-19 ka) began as soon as the foreland piedmont glaciers had melted back into the mountains after the peak of the Würm (i.e. LGM).

\section{The Var system}


141 sea). It extends for $300 \mathrm{~km}$ from the river mouth to the distal area at the base of the northern 142 continental slope of Corsica (Figure 1 and Figure 2). The morphology of the Baie des Anges 143 (offshore Nice) is characterized by a 2-3 $\mathrm{km}$ wide continental shelf, which narrows down to

144100 meters around Nice (Figure 2). The continental slope is very steep (between 6 and 11

$145 \%)$ leading to water depths of 2000 meters at a distance of less than $20 \mathrm{~km}$ from the coast 146 (Pautot, 1981).

Several morpho-sedimentary zones are identified in the Var deep-sea fan: the canyons, the upper valley, the middle valley bordered by the VSR southward, and the lower valley which ends up with a distal narrow turbiditic lobe (Figure 1 and Figure 3). Numerous canyon incisions are detected on the continental shelf and the upper slope, with canyon heads directly connected to the river mouths, in particular those of the Var and the Paillon rivers (Figure 2; Piper and Savoye, 1993). The short connection between terrigeneous sources and canyons contributes to the absence of sedimentation on the continental shelf and explains high sedimentation rates recorded in the basin and on the VSR during the Holocene (Piper and Savoye, 1993). The Var canyon is $25 \mathrm{~km}$ long, going down to water depths of about 1600 meters, with a slope gradient decreasing from $11 \%$ to $4 \%$, locally reaching $15 \%$. The confluence between the Var and the Paillon canyons, at $1650 \mathrm{~m}$ of water depth, marks the beginning of the upper-fan valley which extends for $12 \mathrm{~km}$ to the southeast down to the base of the continental slope (Piper and Savoye, 1993). The transition between the upper and the middle valley displays a sharp break of the slope (Figure 1 and Figure 3). The middle fan valley is bounded to the north by a low and discontinuous levee (Piper and Savoye, 1993), and to the south by a hyper-developed levee system, i.e. the VSR (Figure 1 and Figure 3). 
168 morphologies are not similar to the giant and classical deep-sea fans like the Mississippi and 169 the Amazone fans, or to the Rhône and El Ebro fans which have all been deposited in the 170 post-messinian Mediterranean basin (Savoye et al., 1993). In contrast, the Var turbidite 171 system shows similarities with the Laurentian, Monterey, Celtic and Cap Ferret deep-sea 172 fans, in particular with respect to the development of large asymmetrical muddy levees and 173 erosional channels feeding sandy terminal lobes (Savoye et al., 1993). The Var levee is 174 dominantly depositional and mainly records high-magnitude events able to spill over, which 175 have a strong control on the system architecture as they erode the channel-floor and 176 participate in the construction of the Var Sedimentary Ridge (Mas et al., 2010).

Stratigraphic framework of the VSR

179

180

The first stratigraphic framework of the VSR was established based on seismic data (Savoye et al., 1993). Seismic profiles have previously been used to illustrate the internal organization of the VSR, allowing the identification of regional reflectors, the oldest being dated to 3.3 Ma (Savoye et al., 1993). More recently, Migeon et al. (2001) focused on the stratigraphy of the eastern part of the VSR which is characterized by a field of sediment waves. The formation of these giant sediment waves started before the development of a regional seismic reflector dated to about $1.5 \mathrm{Ma}$ (Savoye et al., 1993).The chronostratigraphic control on top of the sediment waves is based on the $\mathrm{CaCO}_{3}$ content of the sediments which shows a sharp change through the Holocene/Pleistocene boundary (Migeon et al., 2001). The sedimentation rate in the western part of the Ridge has been estimated to about $17 \mathrm{~cm} / \mathrm{ka}$ for the Holocene (Piper and Savoye, 1993) and is about three or four times higher on the eastern part of the Ridge for the Late Quaternary period according to Migeon et al. (2001).

\footnotetext{
contributed to the deposition of sands on the VSR which were inferred to have a slide-related
} 
origin. In addition, late Holocene turbidity currents have deposited thick muddy beds on the

197 VSR, which might result from hyperpycnal flows (Mulder et al., 2001; Mas et al., 2010). The 198 hyperpycnal currents are confined in the upper part of the system and provide only thin deposits (Mas et al., 2010).

200

Late Quaternary climatic/eustatic changes and turbiditic activity

In terms of climate, the transition from the LGM to the Holocene was characterized by major changes in rates of global warming and sea level rise. The $\sim 12 \mathrm{ka}$ of warming since the LGM, first initiated at 19 cal ka BP (Clark et al., 2004), was marked by several intervals of stepwise climatic changes, the Bølling-Allerød interval (between 14.5 and 12.5 cal ka BP) and the Preboreal warming at the beginning of the Holocene (11.5 cal ka BP), being the most preeminent (Alley et al., 2003). Two short intervals characterized by more glacial conditions, referred to as the Oldest Dryas (equivalent to the Heinrich 1 in marine stratigraphy) and the Younger Dryas, also occurred $\sim 18-14.7$ and $\sim 12.5-11.5$ cal ka BP, respectively (Hughen et al., 2000; Alley et al., 2003; Weaver et al., 2003).

Major climate fluctuations in the Mediterranean area are intimately connected to changes in the thermohaline and atmospheric circulation patterns over the North Atlantic

215 (Cacho et al., 1999; Cacho et al., 2000; Sierro et al., 2005). The link between North Atlantic and Mediterranean climate during the last glacial cycle is well documented by frequent episodes of rapid changes in the Mediterranean paleoclimatic records. Throughout the last climatic cycle, episodes of enhanced accumulation of ice-rafted detritus, known as Heinrich events, have been identified in marine sediments from the North Atlantic Ocean and Nordic 220 Seas (Heinrich, 1988; Bond et al., 1992; Grousset et al., 1993; Broecker, 1994; Elliot et al., 221 1998). According to Bard et al. (2000), we define in our study the Heinrich $1(\mathrm{H} 1)$ as the 222 climatic episode ranging from 18.3 and 15.5 cal ka BP, and the $\mathrm{H} 1$ "stricto sensu" (H1ss) as 223 the ice-rafted debris peak centered at 16 cal ka BP (Heinrich, 1988; Bard et al., 2000). At the 
224 time of Heinrich events, the prodigious amounts of fresh water added to the North Atlantic 225 resulted in a decrease in sea surface temperature and salinity in the western Mediterranean 226 Sea (Kallel et al., 1997a; Kallel et al., 1997b; Cacho et al., 1999; Paterne et al., 1999; Cacho 227 et al., 2000; Cacho et al., 2002; Sierro et al., 2005).

The temporal and physical links between changes in temperature and sea level during the last termination (T.I) remain controversial (Kienast et al., 2003; Weaver et al., 2003). Regardless, there were clearly two short intervals of fast sea level change commonly called meltwater pulse $1 \mathrm{~A}$ and meltwater pulse $1 \mathrm{~B}$. During these events, sea level rose by $>40$ and $>11 \mathrm{~mm} / \mathrm{yr}$, respectively, these rates being higher than the average rate during T.I (around $9.5 \mathrm{~mm} / \mathrm{yr}$ ) (Weaver et al., 2003). The climate coolings (e.g., Oldest and Younger Dryas) can be linked to plateaus in the sea level curve (Hanebuth et al., 2000; Weaver et al., 2003). During H1, sea level stand was 100-110 m lower than present (Yokoyama et al., 2001). During H1ss, rate of sea-level rise was significantly lower than during T.I (Lambeck et 238 al., 2002).

\section{Material and methods}

Four piston cores from the VSR were examined in this study (Table 1). Two 243 Kullenberg piston cores, KNI-22 and KNI-23, were collected during the 1993 NICASAR 244 cruise aboard R/V Le Suroît. Two Calypso piston cores, ESSK08-CS05 and ESSK08-CS13 245 were collected during the 2008 ESSDIV cruise aboard the R/V Pourquoi pas?. Cores KNI-22, $246 \mathrm{KNI}-23$ and ESSK08-CS05 were collected along to the levee crest (Figure 3); core ESSK08247 CS13 is located on the southwestern flank of the VSR (Figure 3).

The variation of $\mathrm{Ca}$ was measured on split cores with an Avaatech XRF Core250 Scanner equipped with a variable optical system that enables any resolution between 10 and 
$2510.1 \mathrm{~mm}$. The measurement area has been adjusted at $8 \mathrm{~mm}$, and the stepsize has been set at $2521 \mathrm{~cm}$.

Preliminary core descriptions were made during both NICASAR and ESSDIV cruises, and detailed descriptions were made during the post cruise sampling. Each core was sampled at $10 \mathrm{~cm}$ intervals, purposely excluding turbidites. Sediment samples were disaggregated with Calgon solution and sieved with water using a 125- $\mu \mathrm{m}$ mesh. Fractions were retained and dried again. The $>125-\mu \mathrm{m}$ fractions were examined under a reflected light microscope to qualitatively assess grain composition. Throughout all three cores, carbonate dissolution is modest and planktic foraminifer tests are relatively abundant in hemipelagic sediment intervals. Specimens are well preserved and show no evidence of mud infilling or diagenetic recrystallization (e.g., secondary carbonate cement). Samples were then dry sieved to retain the $>250-\mu \mathrm{m}$ fraction from which tests of specific planktic foraminifer species were identified and picked for oxygen-isotope analyses (15 tests) and for accelerator mass spectrometer (AMS) ${ }^{14} \mathrm{C}$ dating ( $10 \mathrm{mg}$ of monospecific assemblages). foraminifera Globigerina bulloides that calcifies in the surface mixed layer of the water column. Specimens were ultrasonically cleaned in distilled water after careful crushing to release potential sediment infilling. Samples were then roasted under vacuum at $375^{\circ} \mathrm{C}$ for

$2711 / 2 \mathrm{~h}$ to remove organic contaminants. Using a common $100 \%$ phosphoric acid bath at $90^{\circ} \mathrm{C}$, $272 \quad 20-50 \mu \mathrm{g}$ of sample were reacted and analyzed using a GV Isoprime isotope ratio mass 273 spectrometer at University of Pierre \& Marie Curie. Isotope values are reported in delta 274 notation relative to Vienna Peedee belemnite. Repeated analyses of a marble working 275 standard (calibrated against the international standard NBS-19) indicate an accuracy and 276 precision of $0.1 \%$ ( $1 \sigma)$. 

ESSK08-CS13 (Table 2). For each measurement, about 500 specimens ( 10mg) of $G$. bulloides were picked from the $>250 \mu \mathrm{m}$ fraction, washed in an ultrasonic bath with distilled water, and dried. These aliquots were then analyzed at the Poznan Radiocarbon Lab., Poland. Reported radiocarbon ages have been corrected for a marine reservoir effect of 400 years and converted to calendar years using CALIB Rev 6.0 (Reimer et al., 2009). Calibrated kilo years before present will be referred as cal ka BP.

285

Core chronostratigraphies were established through integration of radiocarbon dating (Table 2) and high-resolution planktonic oxygen isotope stratigraphy (see dataset in Supplementary Data). Based on reference Mediterranean planktonic $\delta^{18} \mathrm{O}$ stratigraphies (Cacho et al., 1999; Melki et al., 2009) and on the $\delta^{18}$ O signal of GISP2 Ice Core (Grootes et al., 1993; Steig et al., 1994; Stuiver et al., 1995; Grootes and Stuiver, 1997), additional control points (tie-points) have been included to improve our age model (i.e. transition Bølling-Allerød / Younger Dryas, transition Younger Dryas / Holocene, and 8.2 cal ka BP isotopic event). Uncertainties of the age model are induced by AMS age errors (between 30 and $180 \mathrm{yr}$ ) and by age interpolation between tie-points.

In order to understand the activity of the Var turbiditic system, we have identified and quantified the number of turbiditic layers in our cores. The identification of turbidites consisted of visual description and X-ray analysis of our cores (Figure 4). Criteria used to identify turbidites in cores were lithology, grain size, sedimentary structures, and thickness. Along the VSR, turbidite beds are characterized by $\mathrm{mm}$ - to $\mathrm{cm}$-thick organic-rich layers, mainly composed of fine to medium sand, and present usually sharply eroded basal contacts. On X-ray imagery (figure 4), the progressive transition from dense (dark) contacts to lighter (grey) top of beds, is associated with the typical fining-up trend of turbidite deposits 
304 (Bouma, 1962; Stow and Piper, 1984). X-ray images have also been used to precisely locate

305 the hemipelagic intervals sampled for stable oxygen isotope measurements. been counted using visual description. We have calculated the turbidite deposit frequency based on our chronostratigraphic framework. This quantification represents the minimum value of turbidite recurrence frequency because of erosive losses and/or non-deposit events (i.e. by-pass), and possible amalgamation of flows. cores using the age model. The upper 8-ka limit was chosen because of the larger number of AMS datings $>10$ cal ka BP (Table 2 ) and because this study is predominantly focused on the time window going from the late LGM $(\sim 18-20$ cal ka BP $)$ and the early Holocene $(\sim 8 \mathrm{cal}$ 317 ka BP).

\section{Results}

Sedimentological observations and lithostratigraphy

Cores ESSK08-CS05, KNI-22 and KNI-23 are located on a transect along the crest of the VSR (Figure 3). Core ESSK08-CS05 is located on the western part of the Ridge (1694 m water depth) where levee height exceeds $300 \mathrm{~m}$. The lithological succession is dominated by centimeter to decimeter-thick silty-clay intervals, showing locally small burrows (Figure 5). Inframillimeter to millimeter-thick silty laminae are identified in the upper two metres below the sea floor and change downward to very fine sandy laminae.

Core KNI-22 is located on the levee crest (1900 m water depth) east of ESSK08- 
millimeter-thick silty laminae are observed like in core ESSK08-CS05 (Figure 5). Sandy beds commonly occur at the base of core $\mathrm{KNI}-22$ while the upper half is characterized by more numerous and thicker $(1-2 \mathrm{~cm})$ silty laminae.

Core $\mathrm{KNI}-23$ has been retrieved from the middle part of the Ridge (2130 m water depth) where the height of the levee is about $130 \mathrm{~m}$ (Figure 3). The sedimentological succession shows major lithological changes in comparison with the upstream cores. Silty laminae are more numerous and thicker, and number and thickness of the sandy layers increase downward the core, showing centimetric to pluri-centimetric fine-sand turbidites with locally erosional basal contact (Figure 5).

Core ESSK08-CS13 (2473 m water depth) is located in the southeastern flank of the VSR, south of KNI-23 (Figure 3). This core is characterized by sandy turbidites interbedded with hemipelagic and silty layers (Figure 5). The mean thickness of the sandy turbidites is lower than in core $\mathrm{KNI}-23$. However, similar to core $\mathrm{KNI}-23$, the frequency of sandy turbidites increases downward the core.

Pelagic carbonate-rich intervals contain higher numbers of planktic foraminifers.

350 Several species and genera have been recognized: Globigerinoides ruber, Globigerinoides 351 sacculifer, Globigerina bulloides, Orbulina universa, Globorotalia menardii, Globorotalia 352 inflata, Globorotalia truncatulinoides, Globigerina quiqueloba, Globorotalia scitula, 353 Globigerinoides trilobus, Globorotalia dutertrei, Neogloboquadrina pachyderma. These 354 intervals are intercalated with sandy turbidites at the base of cores $\mathrm{KNI}-22, \mathrm{KNI}-23$ and 355 ESSK08-CS13 and constitute the majority of the sediment in the upper part of the cores. The 356 sand content of the uppermost few meters increases gradually eastward and southward on 357 the VSR, from less than $5 \%$ up to $60 \%$ respectively. Compared to $\mathrm{KNI}-23$, the thinner sandy 358 turbidites found in core ESSK08-CS13 confirms that sand deposition mainly occurs on the 
upstream flank of the levee, as observed in the eastern part of the VSR where a field of giant sediment waves is developed.

The Ca content shows similar trends between all cores (Figure 5). Relative low Ca values are detected at the base of the cores. According to the AMS ${ }^{14} \mathrm{C}$ dates, high $\mathrm{Ca}$ content corresponds to intervals younger than $17 \mathrm{cal}$ ka BP in all cores. The upper 4 meters of all cores display a progressive decreasing of the $\mathrm{Ca}$ and a reversal towards higher values at top of the cores.

The glacial-interglacial transition is clearly identified in all cores (Figure 6). The high $\delta^{18} \mathrm{O}$ values $(>+4 \%$ ) in the lower part of each core clearly correspond to the late LGM $-\mathrm{H} 1$ (between 15.5 and 20 cal ka BP). The low $\delta^{18} \mathrm{O}$ values $(<+2 \%$ ) in the upper part correspond to the Holocene (<11 cal ka BP), and T.I (from 15 to $11 \mathrm{cal}$ ka BP) is characterized by the intermediate $\delta^{18} \mathrm{O}$ values (between $+2 \%$ and $+4 \%$ ). In each record, the $\delta^{18} \mathrm{O}$ amplitude through T.I is similar (approximating $2 \%$ ) and comparable to global signals (e.g., Waelbroeck et al., 2001 among others). The transition from $\mathrm{H} 1$ to T.I is also marked by a sudden increase in the Ca content in all cores (Figure 6).

ESSK08-CS13, they exhibit a common down-core stratigraphic pattern. Except for ESSK08CS05 which displays a small number of turbidites, sandy turbidites older than T.I are numerous in the lower parts of the cores (Figure 6). Intervening silty layers and intervals rich in pelagic carbonates, which become more frequent up the core, separate the turbidites. Based on a primary stratigraphy, it appears that, during T.I, the number of turbidites decreased and rapidly turned into an interval that is dominated by the deposition of pelagic carbonate-rich sediments. During the early Holocene, the deposition of turbidites on the VSR is less dominant than during $\mathrm{H} 1$. 


\section{Age model and event stratigraphy}

The time frame for all cores is based on isotope stratigraphy and $A M S{ }^{14} \mathrm{C}$ dating. The down core variations of $\delta^{18} \mathrm{O}$ in planktic foraminifera $G$. bulloides nicely correlate with the GISP2 high-resolution oxygen isotope record (Figure 6 and Figure 7). The glacial/interglacial transition in all cores, solidly anchored by ${ }^{14} \mathrm{C}$ AMS dates (Table 02), confirmed that these cores span from late LGM (19-20 cal ka BP) to late Holocene and are recording the stepwise last glacial termination typically observed in the Mediterranean basin (Cacho et al., 1999; Melki et al., 2009).

The overall isotopic trend during T.I is expressed by a relatively gradual decrease in $\delta^{18} \mathrm{O}$ values. This trend is interrupted by a significant cold reversal (beginning abruptly at $\sim 12.5 \mathrm{cal}$ ka BP and ending at $\sim 11.5 \mathrm{cal}$ ka BP, Figure 6 , Figure 7) which is bounded by two stepwise warming periods occurring at $\sim 14.5$ and $\sim 11.5$ cal ka BP. The timing of this cold reversal, as indicated by a significant increase of $\delta^{18} \mathrm{O}$ values (down to $+3 \%$, Figure 7 ) and low Ca contents (Figure 6), corresponds relatively well to the timing of the Younger Dryas.

403 The first deglacial step, characterized in the four cores by an abrupt decrease of the $\delta^{18} \mathrm{O}$ and increase of $\mathrm{Ca}$ content (Figure 5 and Figure 6 ) corresponds to the $\mathrm{H} 1$ (18 to 15.5 cal ka BP). The second warming/deglacial step, evidenced by low $\delta^{18} \mathrm{O}$ values (Figure 7) and increasing $\mathrm{Ca}$ content (Figure 6) corresponds most likely to the Bølling-Allerød interval. In cores ESSK08-CS05 and ESSK08-CS13, ${ }^{14} \mathrm{C}$ dates of $15.1 \mathrm{ka}$ and of 13.5 ka precisely indicate this warming event (Table 2). The third warming/deglacial step, identified in the four cores by an abrupt decrease in the $\delta^{18} \mathrm{O}$ and increase of Ca content (Figure 6 and Figure 7) corresponds to the beginning of the Holocene. This warming is well anchored by ${ }^{14} \mathrm{C}$ ages obtained in cores KNI23 and ESSK08-CS05 (Table 2). 
414 The frequency of the turbiditic deposits (turb.500 $\mathrm{yr}^{-1}$ ) has been estimated from all the cores from 20 to 8 cal ka BP (Figure 8). Late LGM to early Holocene deposition rates calculated from the tuned time scale range from $\sim 8$ to $100 \mathrm{~cm} / \mathrm{ka}$ (Figure 8 ). In general, 417 deposition rates were high during the late LGM and $\mathrm{H} 1$ for all the cores, and low during T.I 418 (15 to 11 cal ka BP) (Figure 8). An overall increase in the deposition rates is observed from 41911 to 8 cal ka BP.

420 Four main periods of turbiditic activity are observed (Figure 8):

422

a) From ca. 20 to 17 cal ka BP), there is a general high turbidite activity on the VSR. The turbidite frequency ranges from 0 to 18 turbidites per 500 years (turb.500yr ${ }^{-1}$ ), the thickest deposition of sands being observed at KNI-23 and ESSK08-CS13.

b) From ca 17 to 11 cal ka BP, the turbiditic activity on the VSR started to gradually decrease and became very low at the beginning of T.I (reaching 2 turb.500 $\mathrm{yr}^{-1}$ at $15 \mathrm{cal} \mathrm{ka}$ $\mathrm{BP})$. This gradual decrease of the turbidite deposition is observed in most cores

c) During the Younger Dryas (ca. 12.5 to 11.5 cal ka BP), a sharp increase of the turbidite frequency (max. 5 turb.500yr ${ }^{-1}$ ) is detected in all the cores.

d) At the early Holocene (ca. 11 to 8 cal ka BP), there are few turbidites in cores ESSK08-CS05 and KNI-22 (from 0 to 1 turb.500 $\mathrm{yr}^{-1}$ ), while a moderate turbidite frequency is observed in cores KNI-23 and ESSK08-CS13 (from 1 to 6 turb.500yr ${ }^{-1}$ ). The most important deposition rates and sand accumulation are observed in core ESSK08-CS13.

\section{Discussion}


Analysis of the turbidite frequency displays a heterogeneous deposition and preservation depending on the location along the VSR (Figure 8). Areas located on the highest part of the levee (e.g. location of core ESSK08-CS05, where levee height exceeds $300 \mathrm{~m}$ ) are characterized by a low sand/mud ratio compared to other localities. The increasing sand content along the levee crest may be explained by a higher overflow energy on the eastern part of the levee, linked with a progressive decreasing of the levee height, and allowing a more abundant sand supply. It suggests that the levee height is a significant geomorphological parameter controlling the overflow ability of a turbidity current circulating in the Var canyon, and then the deposition and frequency of silty/sandy turbidites along the VSR. A channel bend would also affect the overflow ability of turbidity currents in the Var Canyon. Core KNI-22 is located at the outer bank of a channel bend and is mostly influenced by combination of centrifugal forces and Coriolis effect. In fact, frequency of turbidites attains maximum during the late LGM in core $\mathrm{KNI}-22$ rather than core $\mathrm{KNI}-23$ where the levee height is minimum. Similarly, the core ESSK08-CS13 is located on down flow position of overbank flows from the location of core $\mathrm{KNI}-22$, which leads to high frequency of turbidite and high deposition rate in core ESSK08-CS13.

456

Comparing the levee crest (cores $\mathrm{KNI}-22$ and $\mathrm{KNI}-23$ ) and the southern area (core ESSK08-CS13), it appears that the highest late LGM turbidite frequencies are observed in the southern part of the levee while the highest deposition rates are located on the levee crest (Figure 8). Due to a higher number of turbidites and a lower deposition rate, the southern area is probably more affected by erosional processes than at the levee crest during glacial times, or perhaps the crest was more often bypassed, causing the lower turbidite frequencies. At the beginning of T.I (around 14 to $15 \mathrm{cal} \mathrm{ka} \mathrm{BP}$ ), the deposition/preservation of turbidites increased on levee crest (location KNI-22 and KNI-23,

465 Figure 8) and decreased on the southern area (ESSK08-CS13, Figure 8). It may suggest a 466 reduction of the velocity and/or increase density of the turbidity currents in the Var canyon, 467 which led to overflows limited to the levee crest. This is in agreement with low turbidite 
frequencies and higher deposition rates in the southern area during T.I, which reflects a higher preservation of hemipelagic sediments (Figure 8). Except in core ESSK08-CS05, the deposition/preservation of turbidites during the Younger Dryas is rather similar on the levee crest and the southern area (Figure 8). The Holocene is characterized by a higher deposition/preservation of turbidites in the southern area (Figure 8).

The partitioning of turbidites from late LGM to early Holocene shows that erosion and deposition processes are closely linked to the morphology (levee height) of the VSR, the velocity of the gravity flow, and the distance from the middle valley. When comparing areas proximal to the channel to the distal levee, we expect that there is a lot of local erosion and bypass, meaning that the observed turbidite frequencies are low estimates. This is in agreement with observations of present sea-level highstand terraces along the Var turbidite system which are affected by turbulent flow erosion (Mas et al., 2010). However, the potential occurrence of local erosion seems to not affect the preservation of a highresolution, long time record of the dynamic of gravity flows.

\section{Climate-induced turbidite activity on the Var system}

Taking into account the presence of a steep and narrow continental shelf and the direct connection between Var and Paillon Rivers and the Var canyon (Figure 2), the activity of the Var system is most probably climate-dependent and not primary related to sea level changes during the last deglacial. This is demonstrated by similar average turbidite frequencies during lowstand ( $-100 \mathrm{~m}$ below present-day sea level at $\sim 15$ cal ka BP) and highstand ( $-15 \mathrm{~m}$ below present-day sea level at $\sim 8$ cal ka BP) of the sea level (Figure 9). In spite of an average turbidite frequency which remained very low during T.I (from 15 to 11 cal ka BP), we note that the decreasing turbidite activity started at about 17 cal ka BP, i.e. 2 ka before the meltwater pulse $1 \mathrm{~A}$, when the relative sea level stood about -100 and $-110 \mathrm{~m}$ below present-day sea level (Figure 9). 
On the VSR, the highest average turbidite frequencies occurred between ca 20 and 17 cal ka BP. Therefore, the most significant turbidite frequencies observed on the VSR coincide with the "Alpine Lateglacial" period defined by Ivy-Ochs et al. (2008), when the foreland piedmont glaciers started to melt back into the mountains after the peak of the LGM

501 (Figure 9). In Alpine drainage basins, this period of extensive glacier melting corresponds to 502 maximum sediment load and water discharge, as demonstrated for the Rhône and Po rivers 503 (Hinderer, 2001; Kettner and Syvitski, 2008). The high turbidite activity in the Var Canyon during the late LGM and first part of $\mathrm{H} 1$ ( 18.4 to 17 cal ka BP) may also relate to the occurrence of an extremely arid and cold climate, which caused the disappearance of most arboreal taxa (Reille et al., 1998; Fauquette et al., 1999; Hinderer, 2001). The glacier melting during the "Alpine Lateglacial" corresponds to the European glaciation evidenced in northern ice-sheets (Toucanne et al., 2009) at the origin of a drastic cooling (Denton et al., 2010; Toucanne et al., 2010). Conjunction of large glacier melting and associated meltwater discharge, available large masses of unconsolidated sediments, and scarce vegetation could explain the largest turbidite activity in the Var canyon from late LGM to H1 (Figure 9). 9) and at 16 cal ka BP (i.e. H1ss), and became significantly low at 15 cal ka BP.

515 Concerning the continental record, the first clear post-LGM readvance of mountain glaciers is 516 recorded by the Gschnitz stadial moraines (Ivy-Ochs et al., 2008), dated at about 16 to $17 \mathrm{ka}$ 517 (Figure 9). A rough estimate indicates that about $80-90 \%$ of the late LGM ice volume was already gone at this time (Ivy-Ochs et al., 2008). The sedimentary record of the VSR doesn't reveal any evidences of the impact of the Gschnitz glaciers melting, showing a very low 520 turbiditic activity from 17 to 15 cal ka BP. (Figure 9). One would expect that turbidite 521 frequency increased during periods of warming and of major glacier-meltwater pulses, 522 occurring at the Bølling-Allerød and at the end of the Younger Dryas. Our case study 523 demonstrates that low turbidite frequencies are observed all along the T.I (Figure 9). The 
524 relative low turbiditic activity in the Var canyon during periods of warming can be explained 525 by much less widespread glacier extent in the Alps that resulted in less glacial generated sediment. In the same time, there was a stronger stabilization of perialpine river basins by soils and vegetation (Reille et al., 1998; Fauquette et al., 1999; Hinderer, 2001).

A synchronous increase in the turbidite frequency in all cores collected on the VSR is observed during the Younger Dryas (Figure 9). The Younger Dryas, known as a global climate reversal, corresponds to 1) a re-advance of many glaciers in the Alps (Ivy-Ochs et al., 2006; Ivy-Ochs et al., 2008; Ivy-Ochs et al., 2009), 2) an increase of the sediment load in the Rhône river (Kettner and Syvitski, 2008), and 3) the dominance of cold steppe biomes in France (Reille et al., 1998; Fauquette et al., 1999; Hinderer, 2001). The transition between the Younger Dryas and the Holocene is marked by the overall stabilization of the turbidite activity in the Var Canyon. Local increases of the turbidite frequency (e.g. on core ESSK08CS13, Figure 8) could be correlated with glacier melting at the end of the Younger Dryas that has triggered glacier and river discharge due to snow melt (Kettner and Syvitski, 2008). Early Holocene average turbidite frequencies remain lower than during the Younger Dryas (Figure 9). This could be attributed to the disappearance of glaciers in early Holocene, in addition to the establishment of warm and cool mixed forest in the major part of France (Fauquette et al., 1999), which decreased the ability for sediments to be eroded and transported towards river mouth and canyon heads (Figure 9).

\section{Comparison with other turbiditic systems}

Compared to other deep-sea systems located in the western Mediterranean basin,

548 the absence of continental shelf in the Nice area makes the VSR a unique mediterranean

549 deep-marine sedimentary environment. The closest turbiditic system is the Rhone Deep Sea

550 Fan which is known as the largest sedimentary body in the western Mediterranean Sea. At

551 this location the last phase of up-building of a channel/levee system (the Rhone Neofan) is 
552 dated back to 18.2 cal ka BP (Bonnel et al., 2005). During the T.I, only four to six post-

553 Neofan sand layers are identified in the area (Bonnel et al., 2005; Dennielou et al., 2009).

554 These sandy layers are interpreted as the product of instabilities from sand banks at the shelf

555 edge since the last sea-level rise, suggesting that most of the deglacial sands delivered by rivers were trapped on the shelf (Jouet et al., 2006) and were occasionally reworked and transported through canyons and deposited in the abyssal plain. Due to the absence of

558 continental shelf, the Var turbiditic system delivers the most complete and the most continuous sedimentary message recording the glacial-deglacial transition in the deepmarine environments from the western Mediterranean basin.

According to Nakajima and Itaki (2007), the temporal changes in turbidite deposition in the Japan Sea may chiefly reflect climate in the source area (the Northern Japan Alps) over the last glacial cycle. During the LGM, the Japan Sea was capped by cold, low-salinity surface water, and the terrestrial climate was cold and dry due to low evaporation from the Japan Sea. As a result of low precipitation, less coarse debris was transported into deep basins, and so during the LGM, the turbidite flux in the Central Japan Sea was reduced (Nakajima and Itaki, 2007). A similar reduced turbidite activity is also observed for the Nile deep-sea turbidite system, this inactivity corresponding to a lowstand in sea-level, and a period of arid climate and relatively low sediment discharge from the Nile fluvial system (Ducassou et al., 2009). Looking at high-latitude turbiditic systems which drainage basins were connected to glaciers (i.e. Lauretian Fan, Celtic Fan, and Var Canyon), it appears that peaks of maximum turbidite activity have occurred during late LGM and first part of $\mathrm{H} 1$

574 (Skene and Piper, 2003; Toucanne et al., 2008), indicating that glacially influenced turbidite systems are largely controlled by ice sheets and glaciers oscillations.

A major difference exists between the VSR and other systems like the Japan Sea or 578 the Nile turbidite system during the deglacial. The Nile turbidite system was more active during periods of rising and high sea-level associated with wetter climates corresponding to 
580 the increase of sediment and water discharge from the Nile (Ducassou et al., 2009). In the 581 Japan Sea, periods of intense turbidite deposition (ca. $15 \mathrm{ka}$ and $10 \mathrm{cal} \mathrm{ka} \mathrm{BP}$ ) correlate with 582 rapid rises in temperature during meltwater pulses $1 \mathrm{~A}$ and $1 \mathrm{~B}$ which have caused a 583 significant transport of coarse sediments (Nakajima and Itaki, 2007) and. A decrease of the 584 turbiditic activity is also observed in the Japan Sea around the Younger Dryas event, and 585 appears to be linked with to lower temperature (Nakagawa et al., 2003) and precipitation with 586 resultant low sediment transport rates. Despite the presence of a narrow continental shelf in 587 both Ligurian and Japan localities, differences in terms of the turbidite deposition during the 588 deglacial period reflect site-specific climate influences. The Japan Sea was most likely 589 influenced by increased temperature and precipitation due to intensified summer monsoons during the T.I (Nakagawa et al., 2002). This resulted in destabilization of mountain slopes 591 and transport of abundant detritus to the lowlands, and consequently, increased turbidite 592 deposition. In the Var system, decrease of the turbidite activity mostly reflects a period with 593 poor glacial generated sediments (Hinderer, 2001) coupled with stabilization of rivers by 594 vegetation and soils (Reille et al., 1998; Fauquette et al., 1999; Hinderer, 2001). Also, taking 595 into account that the Var canyon drainage system is smaller than the Toyama Channel drainage system, the cause of the difference may therefore be attributed to the difference in sediment storage/response time (Blum and Hattier-Womack, 2009) or the difference in the contribution of paraglacial processes (Nakajima et al., 2009).

599 Similar to turbiditic fans located at high latitudes, the sedimentation on the VSR 601 shows a clear influence of climate and glacial changes since the late LGM on the turbiditic activity. Between 17 and 15 cal ka BP, some glacier re-advance periods in Central Europe 603 (Alps and Jura), i.e. Gschnitz, Clavadel, and Daun stadials (Buoncristiani and Campy, 2004a; 604 Ivy-Ochs et al., 2006; Ivy-Ochs et al., 2008), could have been initiated the decrease of the 605 turbidite activity in the Var turbidite system (Figure 8 and Figure 9). A significant decrease of 606 the turbidite activity in the Celtic and the Laurentian turbidite systems also correlates 607 respectively with the re-advance of the European Ice Sheet (Toucanne et al., 2008) and of 
the Laurentide Ice Sheet (Skene and Piper, 2003). These new findings on the Var system

609 confirm that the reduction of the seaward sediment transfert at the end of $\mathrm{H} 1$ was most likely 610 linked to episodic readvance of continental ice sheets, and should stimulate further studies 611 dedicated to the Var drainage basin in order to constrain sediment flux and river discharge in 612 the frame of global climate changes.

613

\section{Conclusions}

615

1- The use of planktic oxygen isotopes and of $\mathrm{AMS}{ }^{14} \mathrm{C}$ dates has allowed the establishment of the first published stratigraphy of the VSR. This high-resolution stratigraphy allows the detection of the activity of the Var canyon and associated overflows during the late glacial/deglacial transition, at millennial timescale resolution.

2- The study of turbidite frequencies demonstrates marked sedimentary partitioning 621 along the Var levee. The levee height acts as an important morphological barrier controlling 622 the deposition and frequency of silty/sandy turbidites along the VSR. In addition, the spatial 623 variability of erosion and deposition seems to have varied since $20 \mathrm{ka}$. Late glacial overflows are mostly recorded at the southern part of the Var levee while deglacial turbidites are preferentially deposited along the levee crest.

3- The turbidite activity in the Var canyon is closely linked to millennial timescale 627 climate changes since the late LGM. Due to the presence of a very narrow continental shelf, 628 timing and nature of the sedimentation along the Var turbiditic levee reflect major changes in 629 glacial condition in the Var drainage basin. These characteristics make the Var Sedimentary 630 Ridge a unique study area for improving our knowledge on how fluctuations in Alpin 631 continental climate have controlled deep-marine sedimentation since the last deglaciation. 633 delivery to the deep ocean changes. Comparison of the Var turbidite system with others high 634 latitude turbiditic fans confirms that the end of the Heinrich 1 corresponds to a decrease in 635 the turbidite activity of channel-levee systems. The instantaneous record of such a climatic 
636 event into deep-marine environments demonstrates that the ability of turbiditic systems to

637 bear extreme climatic fluctuations affecting adjacent lands and rapid seaward transfers of

638 sediment.

639

\section{$640 \quad$ 7. Acknowledgements}

641

642 This work was funded by the IFREMER Geohazards Project. We are grateful to 643 Nathalie Labourdette (Université Pierre \& Marie Curie) who ran oxygen isotope analyses and

644 to Tomasz Goslar who managed the radiocarbon dating at the Poznan Radiocarbon 645 Laboratory (Poland). Samuel Toucanne (IFREMER) is acknowledged for valuable 646 discussions on the stratigraphy of our cores and for the review of early manuscript. We wish 647 to thank Dr. Takeshi Nakajima, Dr. Tor O. Sømme, and Associate Editor David J.W. Piper 648 whose comments and suggestions contributed to improve the original manuscript.

649

650 


\section{References}

651

652

653

654

655

656

657

658

659

660

661

662

663

664

665

666

667

668

669

670

671

672

673

674

675

676

677

678

679

680

681

682

683

684

685

Alley, R.B., Marotzke, J., Nordhaus, W.D., Overpeck, J.T., Peteet, D.M., Pielke, R.A., Pierrehumbert, R.T., Rhines, P.B., Stocker, T.F., Talley, L.D., Wallace, J.M., 2003. Abrupt climate change. Science, 299(5615): 2005-2010.

Bard, E., Rostek, F., Turon, J.L., Gendreau, S., 2000. Hydrological impact of Heinrich Events in the Subtropical northeast Atlantic. Science, 289(5483): 1321-1324.

Blum, M.D., Hattier-Womack, J., 2009. Climate change, sea-level change, and fluvial sediment supply to deepwater depositional systems. In: B. Kneller, O.J. MartinsenB. McCaffrey (Editors), External controls on deep-water depositional systems. SEPM Special Publication, Tulsa, Oklahoma, USA, pp. 15-39.

Bond, G., Heinrich, H., Broecker, W., Labeyrie, L., McManus, J., Andrews, J., Huon, S., Jantschik, R., Clasen, S., Simet, C., Tedesco, K., Klas, M., Bonani, G., Ivy, S., 1992. Evidence for massive discharges of icebergs into the North-Atlantic ocean during the last glacial period. Nature, 360(6401): 245-249.

Bonnel, C., Dennielou, B., Droz, L., Mulder, T., Berne, S., 2005. Architecture and depositional pattern of the Rhone Neofan and recent gravity activity in the Gulf of Lions (western Mediterranean). Marine and Petroleum Geology, 22(6-7): 827-843.

Bouma, A.H., 1962. Sedimentology of some Flysch deposits: a graphic approach to facies interpretation. Elsevier, Amsterdam, $168 \mathrm{pp}$.

Bouma, A.H., 1982. Intraslope basins in northwest Gulf of Mexico: A key to ancient submarine canyons and fans. In: J.S. WatkinsC.L. Drake (Editors), Studies in continental margin geology. Am. Assoc. of Pet. Geol., Tulsa, pp. 567-581.

Bourcart, J., 1960. La Méditerranée et la révolution du Pliocène; L'évolution paléogéographique et structurale des domaines méditerranéens et alpins d'Europe, Livre à la Mémoire du Professeur P. Fallot. Mem. Soc. Géol. Fr., pp. 103-118.

Broecker, W.S., 1994. Massive iceberg discharges as triggers for global climate-change. Nature, 372(6505): 421-424.

Buoncristiani, J.F., Campy, M., 2004a. Expansion and retreat of the Jura ice sheet (France) during the last glacial maximum. Sedimentary Geology, 165(3-4): 253-264.

Buoncristiani, J.F., Campy, M., 2004b. The palaeogeography of the last two glacial episodes in France: the Alps and Jura. In: J. EhlersP. Gibbard (Editors), Quaternary Glaciations - Extent and Chronology. Elsevier, Amsterdam, pp. 101-110.

Cacho, I., Grimalt, J.O., Canals, M., 2002. Response of the Western Mediterranean Sea to rapid climatic variability during the last 50,000 years: a molecular biomarker approach. Journal of Marine Systems, 33: 253-272. 
Cacho, I., Grimalt, J.O., Pelejero, C., Canals, M., Sierro, F.J., Flores, J.A., Shackleton, N., 1999. Dansgaard-Oeschger and heinrich event imprints in Alboran Sea paleotemperatures. Paleoceanography, 14(6): 698-705.

Cacho, I., Grimalt, J.O., Sierro, F.J., Shackleton, N., Canals, M., 2000. Evidence for enhanced Mediterranean thermohaline circulation during rapid climatic coolings. Earth and Planetary Science Letters, 183(3-4): 417-429.

Cacho, I., Shackleton, N., Elderfield, H., Sierro, F.J., Grimalt, J.O., 2006. Glacial rapid variability in deep-water temperature and delta O-18 from the Western Mediterranean Sea. Quaternary Science Reviews, 25: 3294-3311.

Carson, B.E., Francis, J.M., Leckie, R.M., Droxler, A.W., Dickens, G.R., Jorry, S.J., Bentley, S.J., Peterson, L.C., Opdyke, B.N., 2008. Benthic Foraminiferal response to sea level change in the mixed siliciclastic-carbonate system of southern Ashmore Trough (Gulf of Papua). Journal of Geophysical Research-Earth Surface, 113(F1): DOI:10.1029/2006jf000629.

Chough, S.K., Hesse, R., 1977. Channel-fill and spillover facies of Northwest Atlantic midocean channel of Labrador Sea. Aapg Bulletin-American Association of Petroleum Geologists, 61(5): 776-776.

Clark, J.D., Kenyon, N.H., Pickering, K.T., 1992. Quantitative-analysis of the geometry of submarine channels - Implications for the classification of submarine fans. Geology, 20(7): 633-636.

Clark, J.D., Pickering, K.T., 1996. Architectural elements and growth patterns of submarine channels: Application to hydrocarbon exploration. Aapg Bulletin-American Association of Petroleum Geologists, 80(2): 194-221.

Clark, P.U., Marshall McCabe, A., Mix, A.C., Weaver, A.J., 2004. Rapid rise of sea level 19,000 years ago and its global implications. Science, 304: 1141-1144.

Clauzon, G., 1978. The Messinian Var canyon (Provence, Southern France) Paleogeographic implications. Marine Geology, 27(3-4): 231-246.

Clauzon, G., Suc, J.P., Aguilar, J.P., Ambert, P., Cappetta, H., Cravatte, J., Michaux, J., Roiron, P., Rubino, J.L., Savoye, B., Vernet, J.L., 1990. Pliocene geodynamic and climatic evolutions in the French Mediterranean region. Paleontol. Evol., 2: 132-186.

Dennielou, B., Jallet, L., Sultan, N., Jouet, G., Giresse, P., Voisset, M., Berne, S., 2009. Post-glacial persistence of turbiditic activity within the Rhone deep-sea turbidite system (Gulf of Lions, Western Mediterranean): Linking the outer shelf and the basin sedimentary records. Marine Geology, 257(1-4): 65-86.

Droxler, A.W., Schlager, W., 1985. Glacial versus interglacial sedimentation rates and turbidite frequency in the Bahamas. Geology, 13(11): 799-802. 
Dubar, M., Anthony, E.J., 1995. Holocene environmental change and river-mouth sedimentation in the Baie des Anges, French Riviera. Quaternary Research, 43: 329343.

Ducassou, E., Migeon, S., Mulder, T., Murat, A., Capotondi, L., Bernasconi, S.M., Mascle, J., 2009. Evolution of the Nile deep-sea turbidite system during the Late Quaternary: influence of climate change on fan sedimentation. Sedimentology, 56: 2061-2090.

728

729

730

Elliot, M., Labeyrie, L., Bond, G., Cortijo, E., Turon, J.L., Tisnerat, N., Duplessy, J.C., 1998. Millennial-scale iceberg discharges in the Irminger Basin during the last glacial period: Relationship with the Heinrich events and environmental settings. Paleoceanography, 13(5): 433-446.

Evin, M., 1983. Structure et mouvement des glaciers rocheux des Alpes du Sud. Ph.D. Thesis, Université de Grenoble, 343 pp.

Evin, M., Fabre, D., 1990. The distribution of permafrost in rock glaciers of the southern Alps (France). Geomorphology, 3: 57-71.

Fauquette, S., Guiot, J., Menut, M., de Beaulieu, J.-L., Reille, M., Guenet, P., 1999. Vegetation and climate since the last interglacial in the Vienne area (France). Global and Planetary Change, 20(1): 1-17.

Florineth, D., Schluchter, C., 1998. Reconstructing the Last Glacial Maximum (LGM) ice surface geometry and flowlines in the central Swiss Alps. Eclogae Geologicae Helvetiae, 91(3): 391-407.

Foucault, A., Baltzer, F., Glacon, G., Lellouche, D., 1986a. Turbidites and hemipelagites on the southern slope of the Var Ridge (Ligurian Sea, Western Mediterranea). Bulletin de la Sociéte geologique de France, 2(4): 675-679.

Foucault, A., Gennesseaux, M., Clercrenaud, T., 1986b. Submarine sedimentary dunes built by turbidity currents on the southern slope of the Var Ridge (Ligurian Sea, Western Mediterranean). Comptes Rendus De L Academie Des Sciences Serie Ii, 303(12): 1129-\&.

Gennesseaux, M., 1962. Les canyons de la Baie des Anges, leur remplissage sédimentaire, leur rôle dans la sédimentation profonde. Comptes rendus des séances de l'Academie des sciences, Série D, 254: 2409-2411.

Gennesseaux, M., Mauffret, A., Pautot, G., 1980. Les glissements sous-marins de la pente continentale niçcoise et la rupture de câbles en Mer Ligure (Méditerranée Occidentale). Comptes rendus des séances de l'Academie des sciences, Série D, 290: 959-963.

Gibbs, R.J., 1981. Sites of river-derived sedimentation in the ocean. Geology, 9: 77-80. 
Glaser, K.S., Droxler, A.W., 1991. High production and highstand shedding from deeply submerged carbonate banks, Northern Nicaragua Rise. Journal of Sedimentary Petrology, 61(1): 128-142.

Grootes, P.M., Stuiver, M., 1997. Oxygen 18/16 variability in Greenland snow and ice with 10(-3)- to 10(5)-year time resolution. Journal of Geophysical Research-Oceans, 102(C12): 26455-26470.

Grootes, P.M., Stuiver, M., White, J.W.C., Johnsen, S., Jouzel, J., 1993. Comparison of Oxygen-Isotope Records from the Gisp2 and Grip Greenland Ice Cores. Nature, 366(6455): 552-554.

Grousset, F.E., Labeyrie, L., Sinko, J.A., Cremer, M., Bond, G., Duprat, J., Cortijo, E., Huon, S., 1993. Patterns of ice-rafted detritus in the glacial North Atlantic $\left(40^{\circ} \mathrm{S} 55^{\circ} \mathrm{N}\right)$. Paleoceanography, 8(2): 175-192.

Hanebuth, T., Stattegger, K., Grootes, P.M., 2000. Rapid flooding of the Sunda Shelf: A lateglacial sea-level record. Science, 288(5468): 1033-1035.

Heinrich, H., 1988. Origin and consequences of cyclic ice rafting in the Northeast Atlantic Ocean during the past 130,000 years. Quaternary Research, 29(2): 142-152.

Hinderer, M., 2001. Late Quaternary denudation of the Alps, valley and lake fillings and modern river loads. Geodinamica Acta, 14(4): 231-263.

Hiscott, R.N., Pickering, K.T., Bouma, A.H., Hand, B.M., Kneller, B.C., Postma, G., Soh, W., 1997. Basin-floor fans in the North Sea: Sequence stratigraphic models vs. sedimentary facies: Discussion. Aapg Bulletin-American Association of Petroleum Geologists, 81(4): 662-665.

Hughen, K.A., Southon, J.R., Lehman, S.J., Overpeck, J.T., 2000. Synchronous radiocarbon and climate shifts during the last deglaciation. Science, 290(5498): 1951-1954.

Irr, F., 1984. Paléoenvironnements et évolution géodynamique néogènes et quaternaires de la bordure nord du bassin méditerranéen occidental. HDR Thesis, Université de Nice, $464 \mathrm{pp}$.

Ivy-Ochs, S., Kerschner, H., Kubik, P.W., Schluchter, C., 2006. Glacier response in the European Alps to Heinrich Event 1 cooling: the Gschnitz stadial. Journal of Quaternary Science, 21(2): 115-130.

Ivy-Ochs, S., Kerschner, H., Maisch, M., Christl, M., Kubik, P.W., Schluchter, C., 2009. Latest Pleistocene and Holocene glacier variations in the European Alps. Quaternary Science Reviews, 28(21-22): 2137-2149.

Ivy-Ochs, S., Kerschner, H., Reuther, A., Preusser, F., Heine, K., Maisch, M., Kubik, P.W., Schluchter, C., 2008. Chronology of the last glacial cycle in the European Alps. Journal of Quaternary Science, 23(6-7): 559-573. 
Jorry, S.J., Droxler, A.W., Francis, J.M., 2010. Deepwater carbonate deposition in response to re-flooding of carbonate bank and atoll-tops at glacial terminations. Quaternary Science Reviews, 29: 2010-2026.

Jorry, S.J., Droxler, A.W., Mallarino, G., Dickens, G.R., Bentley, S.J., Beaufort, L., Peterson, L.C., Opdyke, B.N., 2008. Bundled turbidite deposition in the central Pandora Trough (Gulf of Papua) since Last Glacial Maximum: Linking sediment nature and accumulation to sea level fluctuations at millennial timescale. Journal of Geophysical Research-Earth Surface, 113(F1): DOI:10.1029/2006jf000649.

Jouet, G., Berne, S., Rabineau, M., Bassetti, M.A., Bernier, P., Dennielou, B., Sierro, F.J., Flores, J.A., Taviani, M., 2006. Shoreface migrations at the shelf edge and sea-level changes around the Last Glacial Maximum (Gulf of Lions, NW Mediterranean). Marine Geology, 234(1-4): 21-42.

Kallel, N., Paterne, M., Duplessy, J.C., VergnaudGrazzini, C., Pujol, C., Labeyrie, L., Arnold, M., Fontugne, M., Pierre, C., 1997a. Enhanced rainfall in the Mediterranean region during the last sapropel event. Oceanologica Acta, 20(5): 697-712.

Kallel, N., Paterne, M., Labeyrie, L., Duplessy, J.C., Arnold, M., 1997b. Temperature and salinity records of the Tyrrhenian Sea during the last 18,000 years. Palaeogeography Palaeoclimatology Palaeoecology, 135(1-4): 97-108.

Kettner, A.J., Syvitski, J.P.M., 2008. Predicting discharge and sediment flux of the Po River, Italy since the Last Glacial Maximum. Spec. Publ. Int. Assoc. Sedimentol., 40: 171189.

Kienast, M., Hanebuth, T.J.J., Pelejero, C., Steinke, S., 2003. Synchroneity of meltwater pulse $1 \mathrm{a}$ and the Bolling warming: New evidence from the South China Sea. Geology, 31(1): 67-70.

Lambeck, K., Esat, T.M., Potter, E.K., 2002. Links between climate and sea levels for the past three million years. Nature, 419(6903): 199-206.

Mas, V., Mulder, T., Dennielou, B., Schmidt, S., Khripounoff, A., Savoye, B., 2010. Multiscale spatio-temporal variability of sedimentary deposits in the Var turbidite system (NorthWestern Mediterranean Sea). Marine Geology, 275(1-4): 37-52.

Melki, T., Kallel, N., Jorissen, F.J., Guichard, F., Dennielou, B., Berne, S., Labeyrie, L., Fontugne, M., 2009. Abrupt climate change, sea surface salinity and paleoproductivity in the western Mediterranean Sea (Gulf of Lion) during the last 28 kyr. Palaeogeography Palaeoclimatology Palaeoecology, 279(1-2): 96-113.

Migeon, S., Mulder, T., Savoye, B., Sage, F., 2006. The Var turbidite system (Ligurian Sea, northwestern Mediterranean) - morphology, sediment supply, construction of turbidite levee and sediment waves: implications for hydrocarbon reservoirs. Geo-Marine Letters, 26(6): 361-371. 
Migeon, S., Savoye, B., Faugeres, J.C., 2000. Quaternary development of migrating sediment waves in the Var deep-sea fan: distribution, growth pattern, and implication for levee evolution. Sedimentary Geology, 133(3-4): 265-293.

Migeon, S., Savoye, B., Zanella, E., Mulder, T., Faugeres, J.C., Weber, O., 2001. Detailed seismic-reflection and sedimentary study of turbidite sediment waves on the Var Sedimentary Ridge (SE France): significance for sediment transport and deposition and for the mechanisms of sediment-wave construction. Marine and Petroleum Geology, 18(2): 179-208.

Mulder, T., Migeon, S., Savoye, B., Faugeres, J.C., 2001. Inversely graded turbidite sequences in the deep Mediterranean: a record of deposits from flood-generated turbidity currents? Geo-Marine Letters, 21(2): 86-93.

Mulder, T., Syvitski, J.P.M., Skene, K.I., 1998. Modeling of erosion and deposition by turbidity currents generated by river mouths. Journal of Sedimentary Research, 68(1): 124-137.

Nakagawa, T., Kitagawa, H., Yasuda, Y., Tarasov, P.E., Nishida, K., Gotanda, K., Sawai, Y., Program, Y.R.C., 2003. Asynchronous climate changes in the North Atlantic and Japan during the last termination. Science, 299(5607): 688-691.

Nakagawa, T., Tarasova, P.E., Nishida, K., Gotanda, K., Yasuda, Y., 2002. Quantitative pollen-based climate reconstruction in central Japan: application to surface and Late Quaternary spectra. Quaternary Science Reviews, 21(18-19): 2099-2113.

Nakajima, T., Itaki, T., 2007. Late Quaternary terrestrial climatic variability recorded in deepsea turbidites along the Toyama Deep-Sea Channel, central Japan Sea. Palaeogeography Palaeoclimatology Palaeoecology, 247(1-2): 162-179.

Nakajima, T., Katayama, H., Itaki, T., 2009. Climatic control on turbidite deposition during the last $70 \mathrm{kyr}$ along the Toyama deep-sea channel, Central Japan Sea. In: B. Kneller, O.J. MartinsenB. McCaffrey (Editors), External controls on deep-water depositional systems. SEPM Special Publication, Tulsa, Oklahoma, USA, pp. 159-177.

Normark, W.R., Piper, D.J.W., Stow, D.A.V., 1983. Quaternary development of channels, levees, and lobes on middle Laurentian Fan. Bulletin American Association of Petroleum Geologists, 67(9): 1400-1409.

Paterne, M., Kallel, N., Labeyrie, L., Vautravers, M., Duplessy, J.C., Rossignol-Strick, M., Cortijo, E., Arnold, M., Fontugne, M., 1999. Hydrological relationship between the North Atlantic Ocean and the Mediterranean Sea during the past 15-75 kyr. Paleoceanography, 14(5): 626-638.

Pautot, G., 1981. Morphologic framework of the Baie des Anges (Nice, Côte d'Azur), instability model of continental slope. Oceanologica Acta, 4(2): 203-\&. 
866

867

868

869

870

871

872

873

874

875

876

877

878

879

880

881

882

883

884

885

886

887

888

889

890

891

892

893

894

895

896

897

898

899

900

901

Pautot, G., Lecann, C., Coutelle, A., Mart, Y., 1984. Morphology and extension of the evaporitic structures of the Liguro Provencal Basin: New SeaBeam data. Marine Geology, 55(3-4): 387-409.

Pierau, R., Hanebuth, T.J.J., Krastel, S., Henrich, R., 2009. Late Quaternary climatic events and sea-level changes recorded by turbidite activity, Dakar Canyon, NW Africa. Quaternary Research, 73(2): 385-392.

Piper, D.J.W., Normark, W.R., 1983. Turbidite depositional patterns and flow characteristics, Navy submarine fan, California borderland. Sedimentology, 30(5): 681-694.

Piper, D.J.W., Savoye, B., 1993. Processes of Late Quaternary turbidity-current flow and deposition on the Var deep-sea fan, Northwest Mediterranean Sea. Sedimentology, 40(3): 557-582.

Reille, M., Andrieu, V., de Beaulieu, J.-L., Guenet, P., Goeury, C., 1998. A long pollen record from Lac du Bouchet, Massif Central, France: for the period ca. 325 to $100 \mathrm{ka}$ BP (OIS 9c to OIS 5e). Quaternary Science Reviews, 17(12): 1107-1123.

Reimer, P.J., Baillie, M.G.L., Bard, E., Bayliss, A., Beck, J.W., Blackwell, P.G., Bronk Ramsey, C., Buck, C.E., Burr, G.S., Edwards, R.L., Friedrich, M., Grootes, P.M., Guilderson, T.P., Hajdas, I., Heaton, T.J., Hogg, A.G., Hughen, K.A., Kaiser, K.F., Kromer, B., MacCormac, F.G., Manning, S.W., Reimer, R.W., Richards, D.A., Southon, J.R., Talamo, S., Turney, C.S.M., van der Plicht, J., Weyhenmeyer, C.E., 2009. Intcal09 and Marine09 radiocarbon age calibration curves, 0-50,000 years cal BP. Radiocarbon, 51(4): 1111-1150.

Sage, L., 1976. La sédimentation à l'embouchure d'un fleuve côtier méditerranéen: le Var. Ph.D. Thesis, Université de Nice, Nice.

Savoye, B., Piper, D.J.W., Droz, L., 1993. Plio-Pleistocene evolution of the Var deep-sea fan off the French Riviera. Marine and Petroleum Geology, 10(6): 550-571.

Schlager, W., Reijmer, J.J.G., Droxler, A.W., 1994. Highstand shedding of carbonate platforms. Journal of Sedimentary Research, 64: 270-281.

Sierro, F.J., Hodell, D.A., Curtis, J.H., Flores, J.A., Reguera, I., Colmenero-Hidalgo, E., Barcena, M.A., Grimalt, J.O., Cacho, I., Frigola, J., Canals, M., 2005. Impact of iceberg melting on Mediterranean thermohaline circulation during Heinrich events. Paleoceanography, 20(2): DOI:10.1029/2004pa001051.

Skene, K.I., Piper, D.J.W., 2003. Late Quaternary stratigraphy of Laurentian Fan: a record of events off the eastern Canadian continental margin during the last deglacial period. Quaternary International, 99: 135-152.

Steig, E.J., Grootes, P.M., Stuiver, M., 1994. Seasonal Precipitation Timing and Ice Core Records. Science, 266(5192): 1885-1886. 
Stow, D.A.V., Piper, D.J.W., 1984. Deep-water fine-grained sediments: facies models. Geological Society, London, Special Publications, 15(1): 611-646.

Stuiver, M., Grootes, P.M., Braziunas, T.F., 1995. The GISP2 delta O-18 climate record of the past 16,500 years and the role of the sun, ocean, and volcanoes. Quaternary Research, 44(3): 341-354.

Thèvenin, J., 1981. Le fleuve Var en aval de Plan du Var et les nappes alluviales, Direction Départementale de l'Agriculture de Nice.

Toucanne, S., Zaragosi, S., Bourillet, J.F., Cremer, M., Eynaud, F., Van Vliet-Lanoe, B., Penaud, A., Fontanier, C., Turon, J.L., Cortijo, E., Gibbard, P.L., 2009. Timing of massive 'Fleuve Manche' discharges over the last 350 kyr: insights into the European ice-sheet oscillations and the European drainage network from MIS 10 to 2 . Quaternary Science Reviews, 28(13-14): 1238-1256.

Toucanne, S., Zaragosi, S., Bourillet, J.F., Marieu, V., Cremer, M., Kageyama, M., Van VlietLanoe, B., Eynaud, F., Turon, J.L., Gibbard, P.L., 2010. The first estimation of Fleuve Manche palaeoriver discharge during the last deglaciation: Evidence for Fennoscandian ice sheet meltwater flow in the English Channel ca 20-18 ka ago. Earth and Planetary Science Letters, 290(3-4): 459-473.

Toucanne, S., Zaragosi, S., Bourillet, J.F., Naughton, F., Cremer, M., Eynaud, F., Dennielou, B., 2008. Activity of the turbidite levees of the Celtic-Armorican margin (Bay of Biscay) during the last 30,000 years: Imprints of the last European deglaciation and Heinrich events. Marine Geology, 247(1-2): 84-103.

Waelbroeck, C., Duplessy, J.C., Michel, E., Labeyrie, L., Paillard, D., Duprat, J., 2001. The timing of the last deglaciation in North Atlantic climate records. Nature, 412(6848): 724-727.

Weaver, A.J., Saenko, O.A., Clark, P.U., Mitrovica, J.X., 2003. Meltwater pulse 1A from Antarctica as a trigger of the bolling-allerod warm interval. Science, 299(5613): 17091713.

Yokoyama, Y., Esat, T.M., Lambeck, K., 2001. Last glacial sea-level change deduced from uplifted coral terraces of Huon Peninsula, Papua New Guinea. Quaternary International, 83-5: 275-283. 
934

935

\begin{tabular}{lllllll} 
Core & Cruise & R/V & Latitude & Longitude & Water Depth $(\mathrm{m})$ & Length $(\mathrm{cm})$ \\
\hline KNI-22 & NICASAR & Le Suroît & $43^{\circ} 21^{\prime} .75 \mathrm{~N}$ & $07^{\circ} 32^{\prime} .63 \mathrm{E}$ & 1900 & 849 \\
KNI-23 & NICASAR & Le Suroît & $43^{\circ} 23^{\prime} .02 \mathrm{~N}$ & $07^{\circ} 44^{\prime} .19 \mathrm{E}$ & 2130 & 1052 \\
ESSK08-CS05 & ESSDIV & Pourquoi Pas? & $43^{\circ} 23^{\prime} .60 \mathrm{~N}$ & $7^{\circ} 25^{\prime} .190 \mathrm{E}$ & 1694 & 2878 \\
ESSK08-CS13 & ESSDIV & Pourquoi Pas? & $43^{\circ} 23^{\prime} .22 \mathrm{~N}$ & $7^{\circ} 47^{\prime} .817 \mathrm{E}$ & 2473 & 2450 \\
\hline
\end{tabular}

936 Table 1: Location, bathymetry and length of the studied cores.

937

\begin{tabular}{lccccccc} 
Lab Code & Core & $\begin{array}{c}\text { Depth } \\
\text { cmbsf }\end{array}$ & $\begin{array}{c}\text { AMS }{ }^{14} \text { C Age } \\
\text { (G. bulloides) ka }\end{array}$ & $\begin{array}{c}\text { AMS }{ }^{14} \text { C Age } \\
(-400 y r)\end{array}$ & Error yr & $\begin{array}{c}1 \sigma \text { Cal BP age } \\
\text { ranges }\end{array}$ & $\begin{array}{c}\text { Cal BP Age (ka) } \\
\text { median probability }\end{array}$ \\
\hline Poz-33957 & KNI-22 & 263.5 & 6.540 & 6.140 & 80 & $6.540-7.152$ & $\mathbf{7 . 0 5 2}$ \\
Poz-33958 & KNI-22 & 475.5 & 13.440 & 13.040 & 60 & $15.237-15.953$ & $\mathbf{1 5 . 7 1 9}$ \\
Poz-33959 & KNI-22 & 689.5 & 16.880 & 16.480 & 80 & $19.448-19.793$ & $\mathbf{1 9 . 5 8 5}$ \\
Poz-33983 & KNI-23 & 200.5 & 3.890 & 3.490 & 50 & $3.800-3.950$ & $\mathbf{3 . 8 6 3}$ \\
Poz-33984 & KNI-23 & 320.5 & 8.890 & 8.490 & 60 & $9.477-9.609$ & $\mathbf{9 . 5 4 9}$ \\
Poz-33985 & KNI-23 & 383.5 & 10.540 & 10.140 & 80 & $11.425-11.943$ & $\mathbf{1 1 . 7 4 1}$ \\
Poz-33987 & KNI-23 & 454.5 & 13.850 & 13.450 & 80 & $16.476-16.786$ & $\mathbf{1 6 . 6 1 0}$ \\
Poz-33988 & KNI-23 & 684.5 & 16.690 & 16.290 & 110 & $19.316-19.570$ & $\mathbf{1 9 . 4 4 2}$ \\
Poz-33960 & ESSK08-CS05 & 234.5 & 3.805 & 3.405 & 30 & $3.703-3.807$ & $\mathbf{3 . 7 5 2}$ \\
Poz-33962 & ESSK08-CS05 & 345.5 & 8.805 & 8.405 & 35 & $9.446-9.506$ & $\mathbf{9 . 4 7 4}$ \\
Poz-33989 & ESSK08-CS05 & 436.5 & 13.090 & 12.690 & 180 & $14.508-15.261$ & $\mathbf{1 4 . 9 6 8}$ \\
Poz-34445 & ESSK08-CS05 & 486.5 & 14.770 & 14.370 & 80 & $17.241-17.626$ & $\mathbf{1 7 . 4 6 9}$ \\
Poz-33992 & ESSK08-CS05 & 596.5 & 17.070 & 16.670 & 100 & $19.572-19.949$ & $\mathbf{1 9 . 8 0 3}$ \\
Poz-33994 & ESSK08-CS13 & 300.5 & 12.080 & 11.680 & 180 & $13.364-13.720$ & $\mathbf{1 3 . 5 4 0}$ \\
Poz-34446 & ESSK08-CS13 & 447.5 & 13.930 & 13.530 & 70 & $16.595-16.826$ & $\mathbf{1 6 . 6 9 7}$ \\
Poz-34150 & ESSK08-CS13 & 678.5 & 17.720 & 17.320 & 100 & $20.334-20.926$ & $\mathbf{2 0 . 6 2 7}$ \\
\hline & & & & & &
\end{tabular}

939 Table 2: Radiocarbon dates of cores KNI-22, KNI-23, ESSK08-CS05, and ESSK08-CS13.

\section{Supplementary information}

943

944 Table showing $\delta^{18} \mathrm{O}$ values and age model for all the studied cores on the Var Sedimentary

945 Ridge. Red values correspond to $\mathrm{AMS}^{14} \mathrm{C}$ dates. 


\section{Figure captions}

Figure 1: Location map of the Var turbidite system in the Ligurian basin.

950

951 Figure 2: Detail of the Var drainage basin and of the connectivity between rivers and

952 submarine canyons. Extent of LGM glaciers and ice flows on the Southern Alps are reported 953 after Buoncristiani and Campy (2004b).

954

Figure 3: Bathymetry of the Var Sedimentary Ridge (contour interval in meters) and location 956 of the studied cores..

957

958

Figure 4: Identification of turbidites (dark layers) on X-rayed slabs $(A)$ and on core pictures 959 (B).

960

Figure 5: Lithological logs, fluctuations of Calcium XRF (10 point-running mean), and AMS

${ }^{14} \mathrm{C}$ dates (cal ka BP) in core ESSK08-CS05, KNI-22, KNI-23, and ESSK08-CS13.

963

964 Figure 6: Lithostratigraphy of the studied cores. Planktonic oxygen isotopes, Calcium XRF, 965 and location of sandy turbidites in core ESSK08-CS13 (A), KNI-23 (B), KNI-22 (C), and 966 ESSK08-CS05 (D). E: $\delta^{18}$ O in GISP2 (Grootes et al., 1993; Steig et al., 1994; Stuiver et al., 967 1995; Grootes and Stuiver, 1997). Black dots show the ice rafted debris (IRD) in number per 968 gram recorded in the subtropical northeast Atlantic (Bard et al., 2000). T.I is the last climatic 969 termination, $\mathrm{H} 1$ is the Heinrich 1 (15.5 to $18.3 \mathrm{cal}$ ka BP, as defined in Bard et al. (2000)), $970 \mathrm{H} 1 \mathrm{ss}$ is the Heinrich 1 stricto sensu (centered at $16 \mathrm{cal}$ ka BP, as defined in Heinrich (1988) 971 and in Bard et al. (2000)), and late LGM is the late Last Glacial Maximum (21 to 18.3 cal ka 972 BP). 
974 Figure 7: Age model based on planktonic oxygen isotopes and $\mathrm{AMS}{ }^{14} \mathrm{C}$ dates, compared to 975 the $\delta^{18}$ O signal of GISP2 Ice Core (Grootes et al., 1993; Steig et al., 1994; Stuiver et al., 976 1995; Grootes and Stuiver, 1997). Late LGM is the late Last Glacial Maximum, H1 is the 977 Heinrich 1, H1ss is the Heinrich 1 stricto sensu, BA is the Bølling-Allerød, and YD is the 978 Younger Dryas).

979

980 Figure 8: Deposition rates, sand thickness, and frequency of overflow deposits observed on 981 the Var Sedimentary Ridge, from 20 to $8 \mathrm{ka}$. LGM is the Last Glacial Maximum, $\mathrm{H} 1$ is the 982 Heinrich 1, H1ss is the Heinrich 1 stricto sensu, BA is the Bølling-Allerød, and YD is the 983 Younger Dryas.

984

985 Figure 9: Relationships between glacial changes in the Alps and turbidite frequency on the 986 Var Sedimentary Ridge since the late LGM. A: Age model of all cores. The red line 987 represents the 9-point moving average calculated on the overall $\delta^{18} \mathrm{O}$ values. Late LGM is the 988 late Last Glacial Maximum, $\mathrm{H} 1$ is the Heinrich $1, \mathrm{H} 1 \mathrm{ss}$ is the Heinrich 1 stricto sensu, $\mathrm{BA}$ is 989 the Bølling-Allerød, and YD is the Younger Dryas; B: Average sand thickness deposited on 990 the Var Sedimentary Ridge; C: Average turbidite frequency and average deposition rate; D: 991 Changes in the relative sea level from far-field sites (after Alley et al., 2003); E: Rhône 992 glacier area (after Kettner and Syvitski, 2008), and time-distance diagram in the Swiss Alps 993 and forelands, Davos region (after Ivy-Ochs et al., 2008). Main glaciations (i.e. stadials) are 994 indicated; F: Fluctuations in tree pollen from Lac du Bouchet, Massif Central (Reille et al., 995 1998).

996 
FIGURE 1






\section{FIGURE 2}

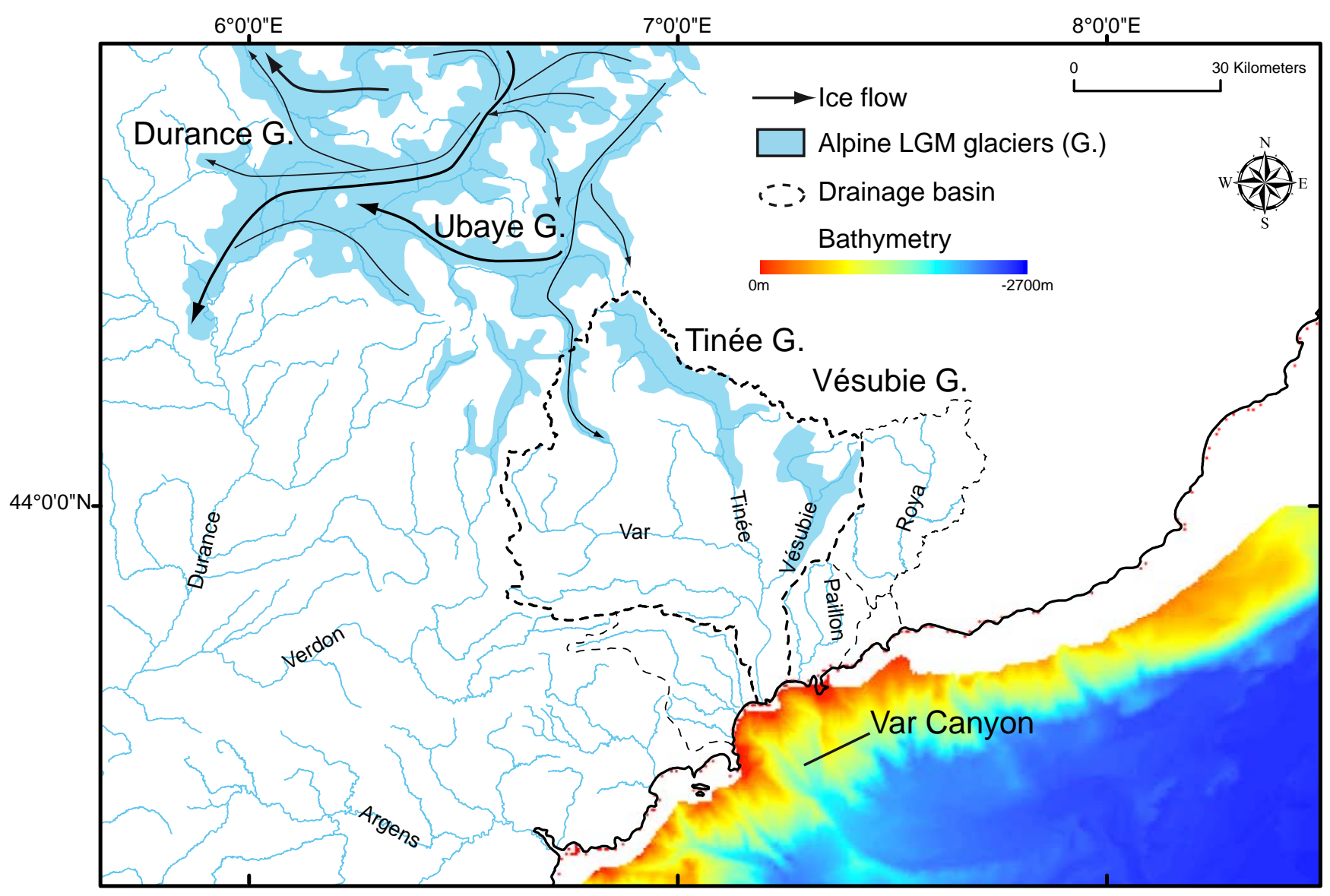


FIGURE 3

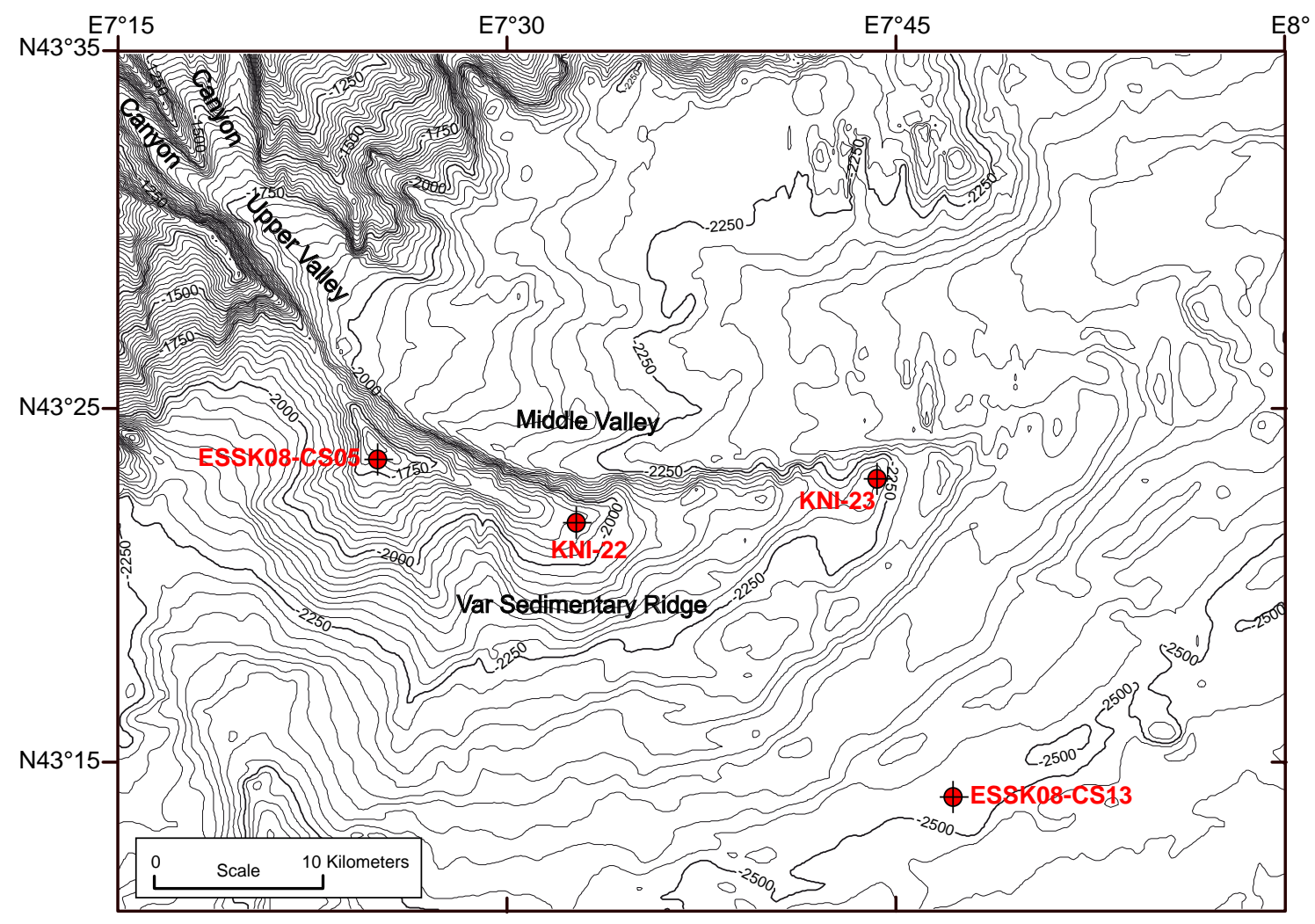


FIGURE 4
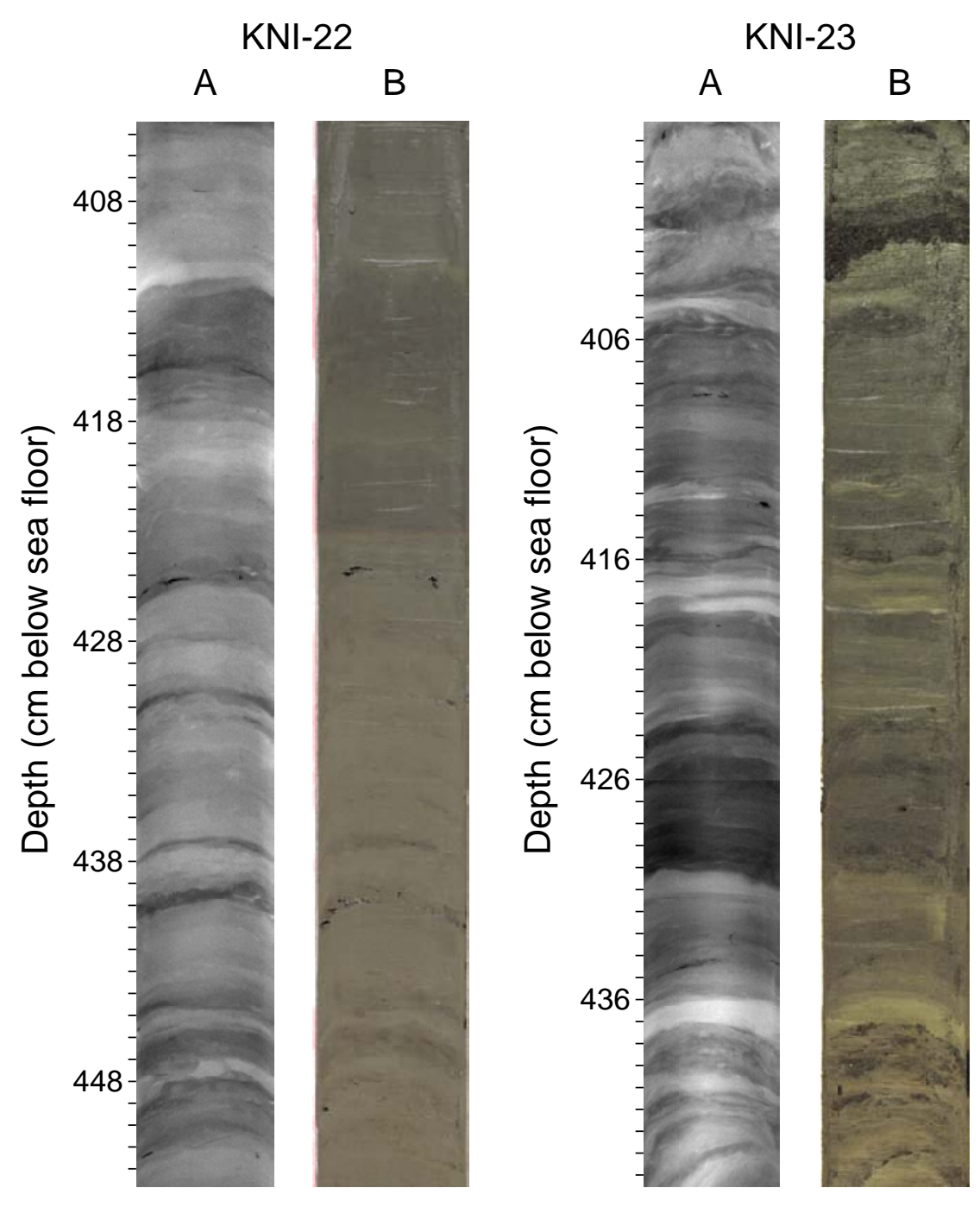
FIGURE 5

ESSK08-CS05

KNI-22

KNI-23

ESSK08-CS13

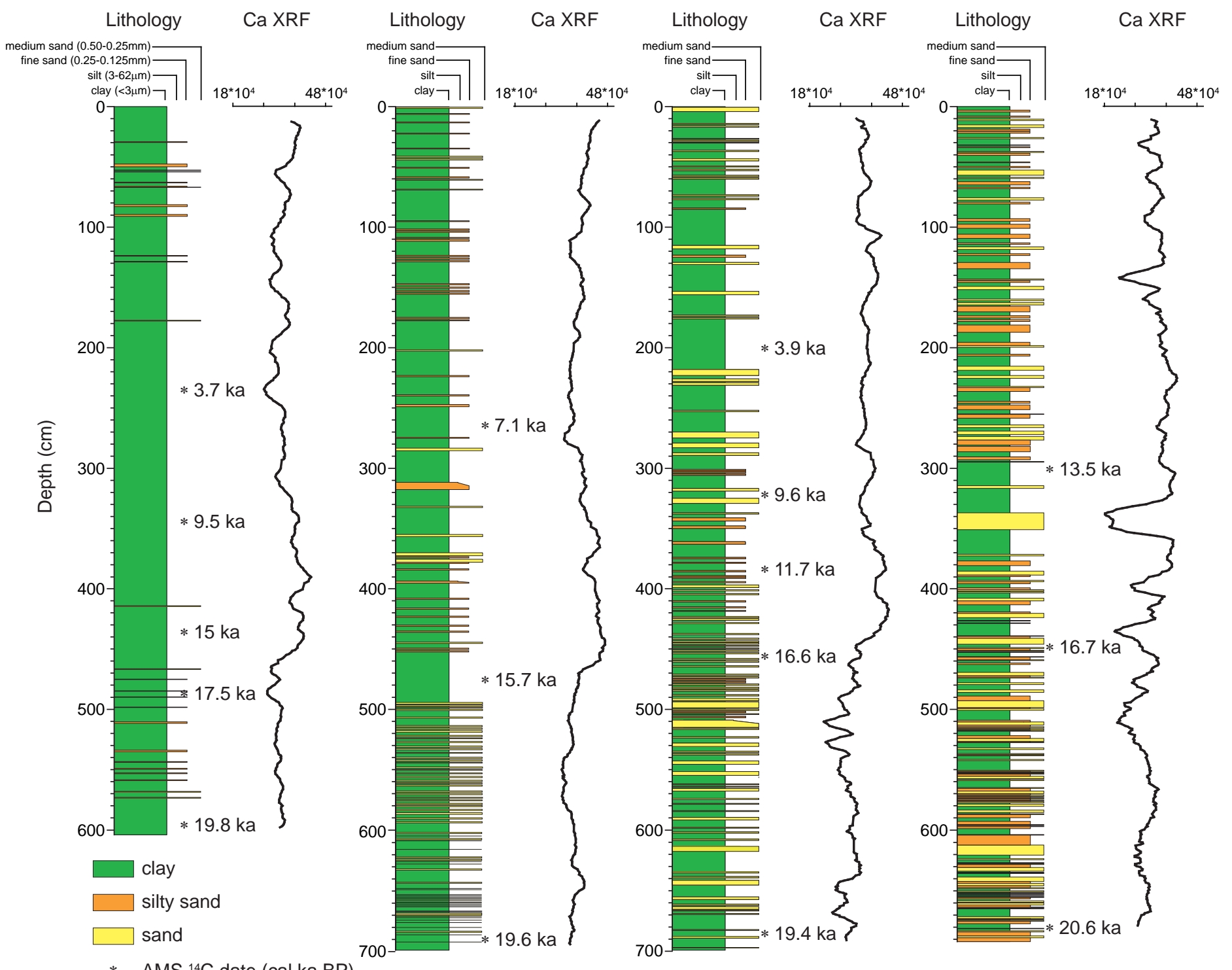




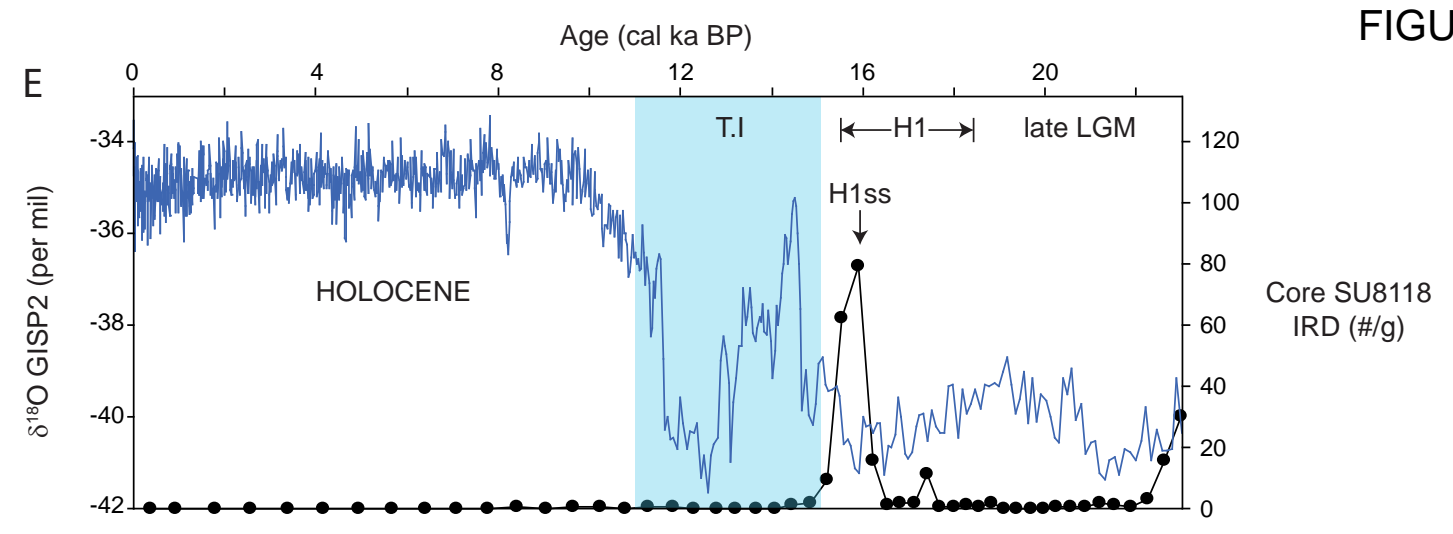

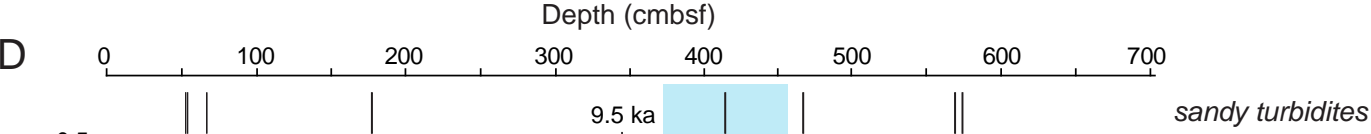
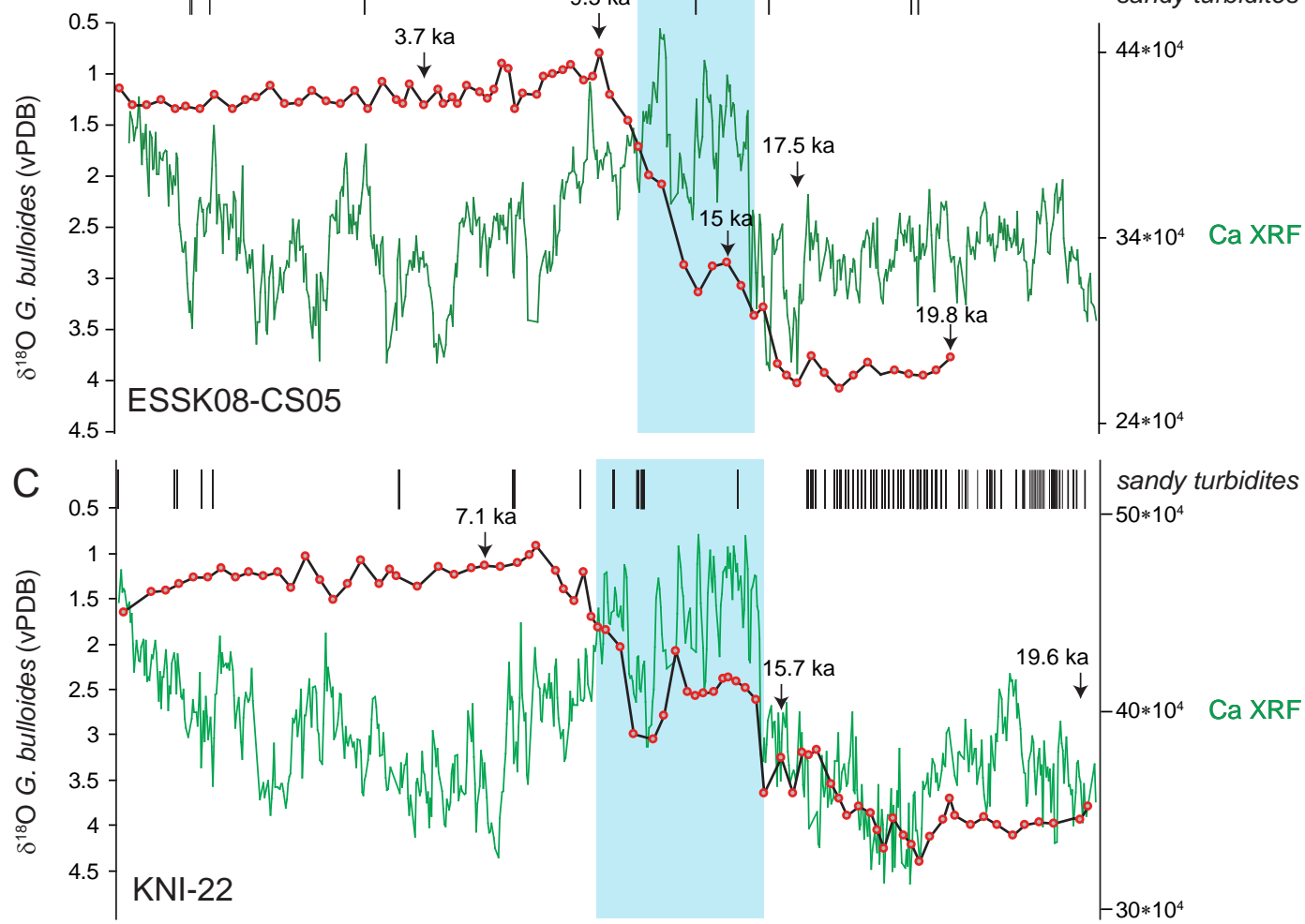

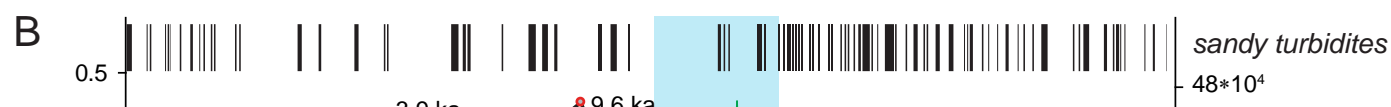
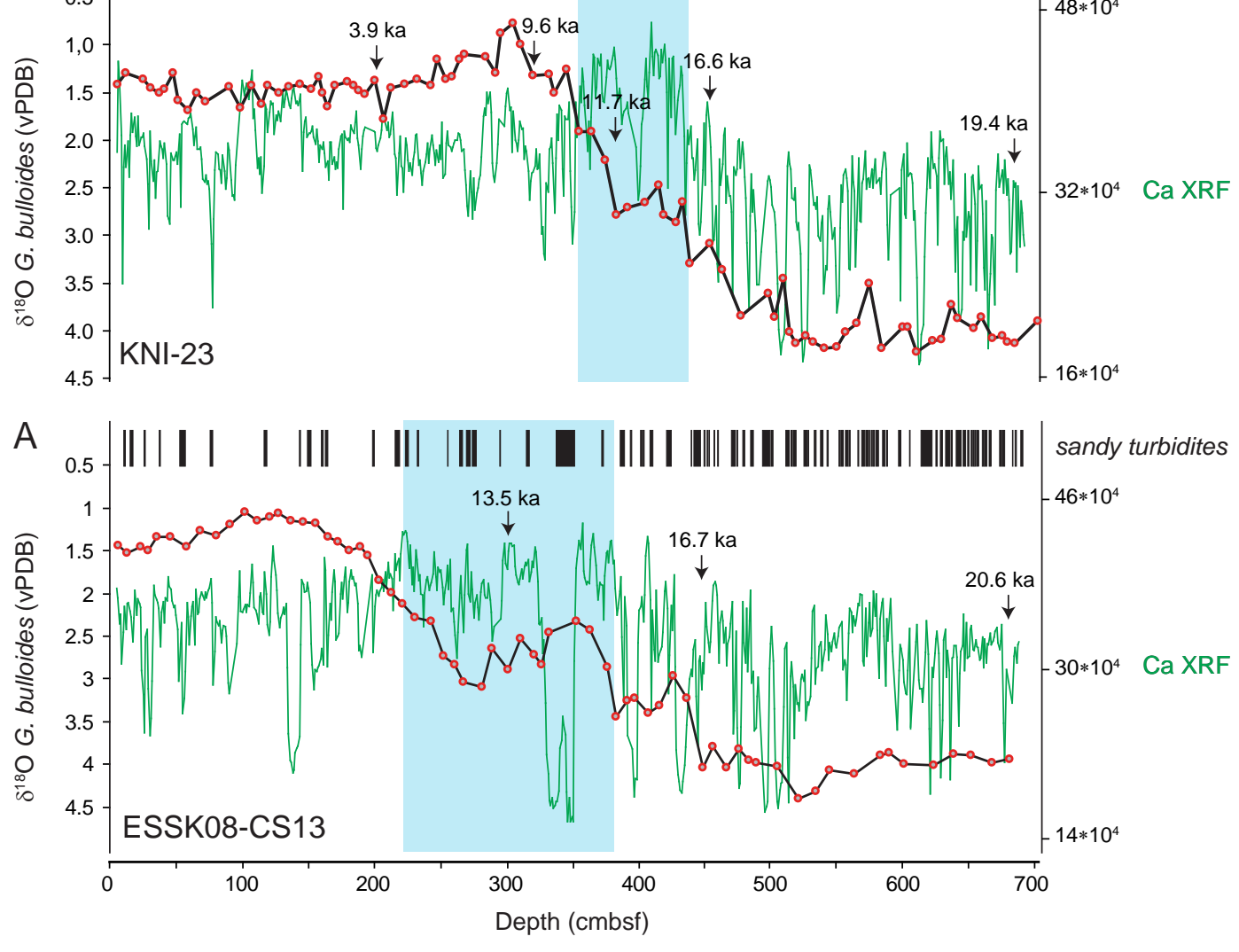
FIGURE 7

Age (cal ka BP)

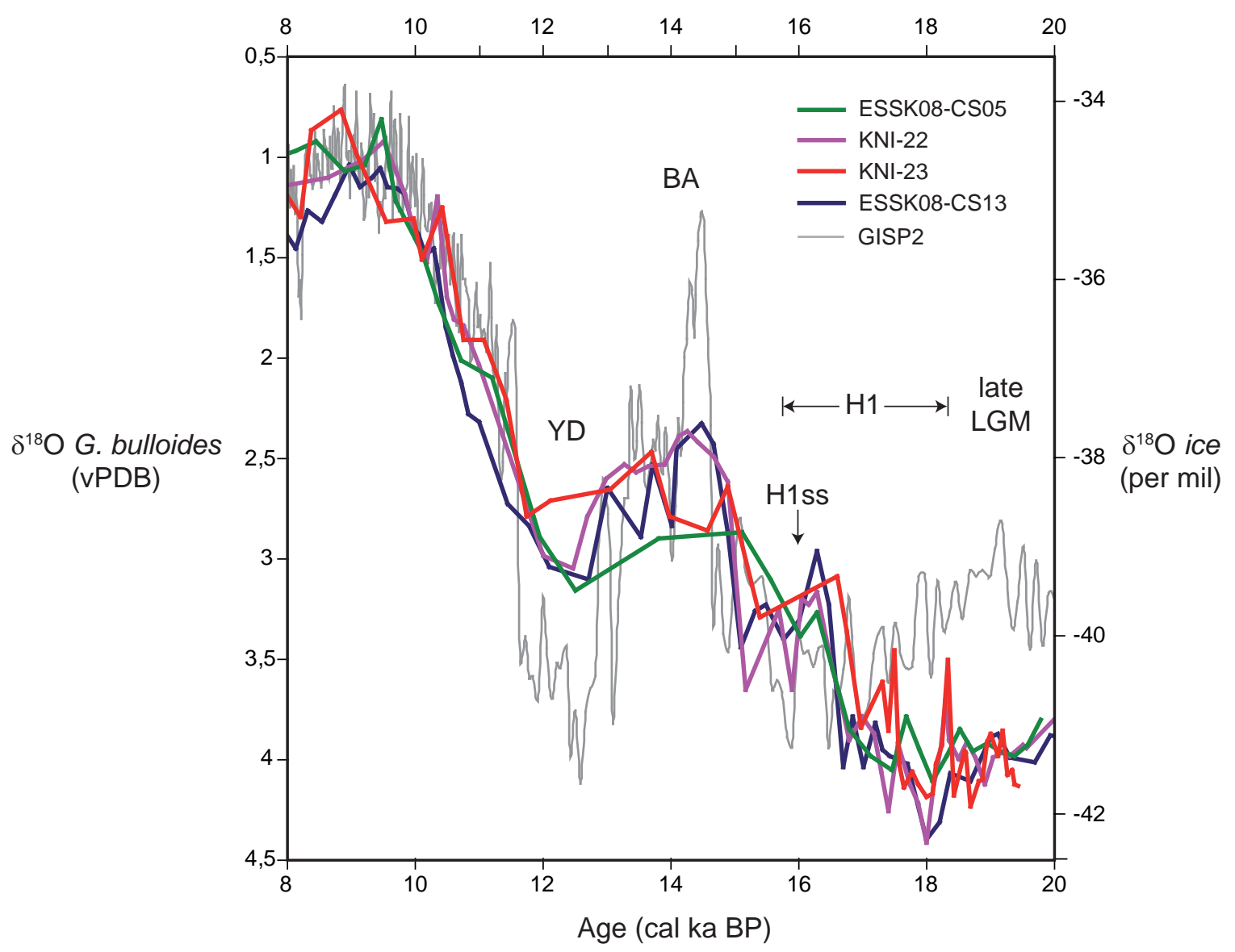




\section{FIGURE 8}

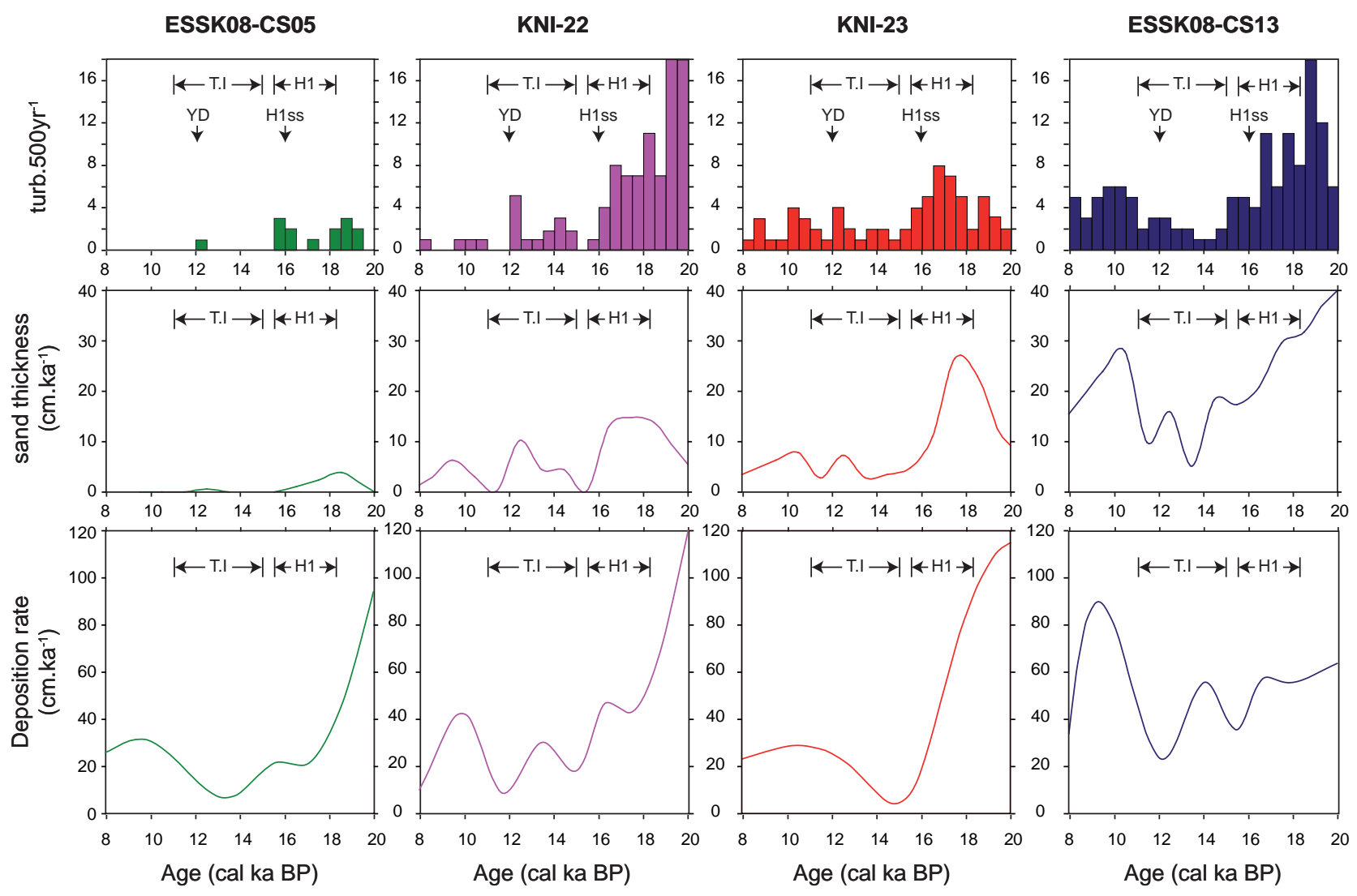


FIGURE 9

F
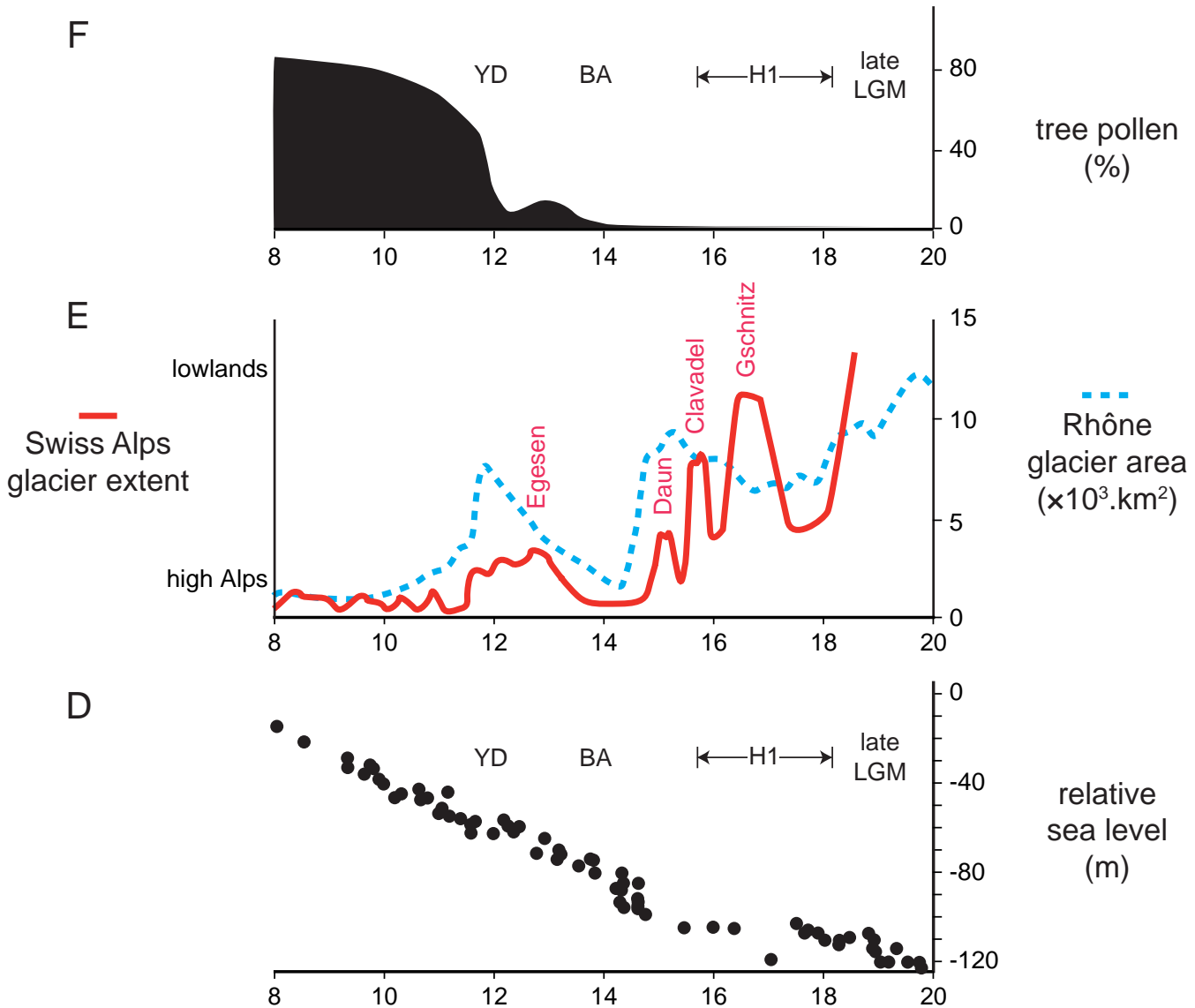

relative sea level

(m)
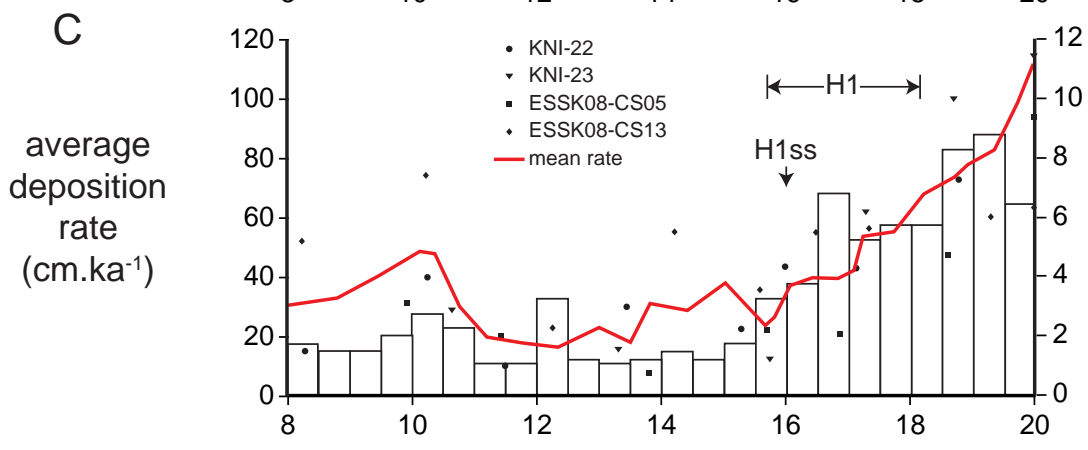

average turb.500yr ${ }^{-1}$

B

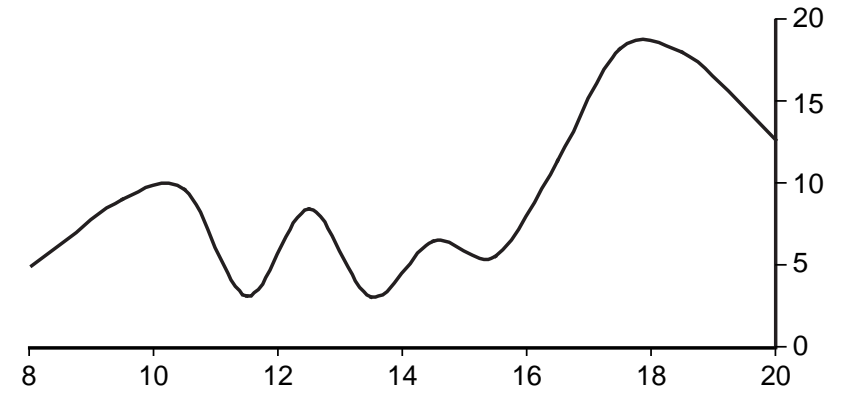

mean sand thickness (cm.ka-1)

A

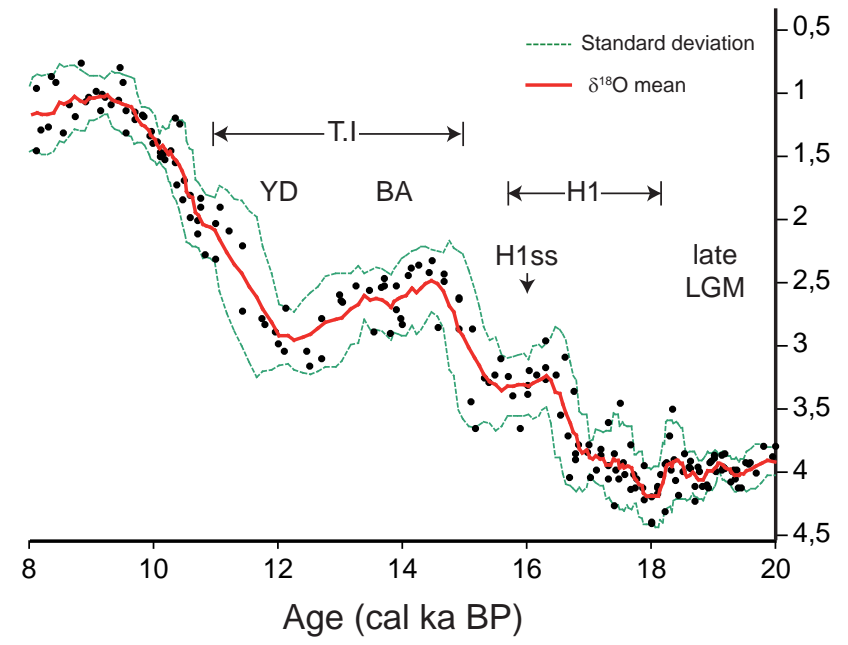

